\title{
Monitoring of a quasi-stationary eddy in the Bay of Biscay by means of satellite, in situ and model results
}

\author{
Ainhoa Caballero ${ }^{\mathrm{a}, *}$, Luis Ferrer $^{\mathrm{a}}$, Anna Rubio ${ }^{\mathrm{a}}$, Guillaume Charria ${ }^{\mathrm{b}}$, Benjamin H. Taylor $^{\mathrm{c}}$, \\ Nicolas Grima ${ }^{d}$
}

\author{
${ }^{a}$ AZTI-Tecnalia, Marine Research Division, Herrera kaia portualdea z/g, 20110 Pasaia, Spain \\ ${ }^{\mathrm{b}}$ Ifremer, Dyneco, BP70, 29280 Plouzané, France \\ ${ }^{c}$ Plymouth Marine Laboratory, PL1 3DH Plymouth, United Kingdom \\ d Laboratoire de Physique des Océans - UMR 6523 - CNRS-IFREMER-IRD-UBO, Brest, France \\ *: Corresponding author : Ainhoa Caballero, email address : acaballero@azti.es
}

\begin{abstract}
:
The presence of a quasi-stationary anticyclonic eddy within the southeastern Bay of Biscay (centred around $44^{\circ} 30^{\prime} \mathrm{N}-4^{\circ} \mathrm{W}$ ) has been reported on various occasions in the bibliography. The analysis made in this study for the period 2003-2010, by using in situ and remote sensing measurements and model results shows that this mesoscale coherent structure is present almost every year from the end of winter-beginning of spring, to the beginning of fall. During this period it remains in an area limited to the east by the Landes Plateau, to the west by Le Danois Bank and Torrelavega canyon and to the northwest by the Jovellanos seamount. All the observations and analysis made in this contribution, suggest that this structure is generated between Capbreton and Torrelavega canyons. Detailed monitoring from in situ and remote sensing data of an anticyclonic quasi-stationary eddy, in 2008, shows the origin of this structure from a warm water current located around $43^{\circ} 42^{\prime} \mathrm{N}-3^{\circ} 30 \mathrm{~W}$ in midJanuary. This coherent structure is monitored until August around the same area, where it has a marked influence on the Sea Level Anomaly, Sea Surface Temperature and surface Chlorophyll-a concentration. An eddy tracking method, applied to the outputs of a numerical model, shows that the model is able to reproduce this type of eddy, with similar 2D characteristics and lifetimes to that suggested by the observations and previous works. This is the case, for instance, of the simulated MAY04 eddy, which was generated in May 2004 around Torrelavega canyon and remained quasistationary in the area for 4 months. The diameter of this eddy ranged from 40 to $60 \mathrm{~km}$, its azimuthal velocity was less than $20 \mathrm{~cm} \mathrm{~s}^{-1}$, its vertical extension reached $3000-3500 \mathrm{~m}$ depth during April and May and it was observed to interact with other coherent structures.
\end{abstract}

Keywords : Bay of Biscay ; Eddies ; SWODDIES ; Topographic effects ; Vortex ; Mesoscale ; Altimetry ; Satellite oceanography ; Drifters ; ROMS

\section{Introduction}

Several studies have shown observational evidence of westward propagation of mesoscale eddies in the open ocean. In the subtropical eastern North Atlantic a subtropical ring called STORM that moved westward near Azores in 1995, was analysed by means of current meter moorings, ARGOS buoys and subsurface floats 
(Pingree et al., 1996). This mesoscale structure was subsequently studied by Pingree and Sinha (1998) combining, in this occasion, in situ data with altimetry. Based also on in situ and remote sensing (altimeter/SeaWiFS) measurements, a westward propagating eddy at $26 \mathrm{~N}^{\circ}$ (generated south of the Canary Islands) and called SWESTY was analysed and followed for > 500 days in 1993 and 1994, by an ARGOS buoy (Pingree, 1996; Pingree and Garcia-Soto, 2004). More recent studies using satellite altimetry also show observational evidence of the westward propagation of eddies (e.g. Morrow et al., 2004; Chelton et al., 2007; Sangrà et al., 2009).

The westward propagation of mesoscale eddies in a $\beta$-plane occurs, regardless of their polarization, due to the variation of the Coriolis parameter with latitude (CushmanRoisin and Beckers, 2011). Also consistent with theory, global observations show small opposing meridional poleward and equatorward deflections of cyclones and anticyclones, respectively (Chelton et al., 2007; Chelton et al., 2011). However, the translational behaviour of mesoscale eddies has been observed to be more complicated when other processes are added to the potential vorticity balance in a $\beta$ plane, due to (i) the presence of a sloping bottom (topographic $\beta$-effect), which as the Coriolis gradient with latitude, causes a translation of eddies with the shallower region to its right in the northern hemisphere (Nof, 1983; Cushman-Roisin and Beckers, 2011); (ii) the interaction with bathymetric irregularities (e.g. submarine seamounts, canyons); (iii) eddy-eddy interactions; or (iv) interactions of eddies with existing currents. Furthermore, on some occasions these processes can become an obstacle to the eddy translation. In these cases, eddies can remain trapped near the same position during part of their lifetimes. Examples of these so-called quasi-stationary eddies have been observed in different locations of the global ocean. In the northeastern Indian Ocean, a stationary counter-clockwise eddy was observed, between the Cuvier basin and the Exmouth Plateau (Metso et al., 1986; Quadfasel et al., 1996). A similar situation occurred in the northern North Atlantic, where the North Atlantic Current formed quasi-stationary meanders (Shoosmith et al., 2005). In that study, looping RAFOS floats monitored a number of quasi-stationary eddies in different places. As an example, to the west of the Mid Atlantic ridge, an anticyclonic eddy remained over a slightly elevated sea-floor area for 9 months, from October 1997. In the California Current System, a $\sim 500 \mathrm{~m}$ high nearly-cylindrically-symmetrical seamount and other topographic disturbances, may either generate and/or trap some offshore eddies by means of barotropic effects (Bernstein et al., 1977; Burkov and Pavlova, 1980; Simpson, 1982; Simpson et al., 1984). Above the topographic anomaly, Zapiola Rise $\left(45^{\circ} \mathrm{S}\right.$ and $\left.45^{\circ} \mathrm{W}\right)$, an intense anticyclonic gyre of barotropic circulation has been observed and modeled in several studies (e.g. Saunders and King, 1995; Volkov and $\mathrm{Fu}, 2008)$. The Zapiola anticyclone is maintained by eddy-topography interactions and controlled by the bottom friction (de Miranda et al., 1999). Finally, these are some examples of quasi-stationary eddies in the eastern North Atlantic: a dipole partially trapped to East Thulean Rise and monitored during more than half a year by an Argos buoy in 1990 (Pingree and Le Cann, 1991); a MEDDY trapped for 11 months in 1997 northeast of the Charcot seamount $\left(45^{\circ} \mathrm{N}, 11^{\circ} 30^{\prime} \mathrm{W}\right)$ (Paillet et al., 2002); A NACW 
anticyclonic eddy monitored from 2000 to 2001, which described a small total displacement, in the northeast Atlantic ( $\left.43^{\circ} 30^{\prime} \mathrm{N}, 1^{\circ}-19^{\circ} \mathrm{W}\right)$ (Reverdin et al., 2009).

Within the southeastern Bay of Biscay (Fig. 1), quasi-stationary eddies have been reported for different years near the same position, around $44^{\circ} \mathrm{N}-4^{\circ} \mathrm{W}$ (Pingree and Le Cann, 1992a; Pingree and Le Cann, 1992b; Garcia-Soto et al., 2002; Caballero et al., 2008). These eddies have been observed to remain stationary for a long time, in some cases up to 7 months (Pingree and Le Cann, 1992b). Due to the location of these eddies near $4^{\circ} \mathrm{W}$ in different years, they have been named " $4^{\circ} \mathrm{W}$ eddies". Pingree and Le Cann (1992a) concluded that the $4^{\circ} \mathrm{W}$ eddies were trapped by the topography, in a recess limited to the west by the combined slope feature of Le Danois bank and Torrelavega canyon and to the east by the Landes Plateau, and that they were usually associated with cyclones. The study of a $4^{\circ} \mathrm{W}$ eddy by means of SST images, Argos buoys and XBTs (Pingree and Le Cann, 1992b) concluded that (i) the characteristics of this eddy were similar to that of Slope Water Oceanic Eddies (SWODDIES) (Pingree and Le Cann, 1992b); (ii) it had a diameter of $100 \mathrm{~km}$, a vertical extension of $>2000 \mathrm{~m}$ (XBTs are limited to $\sim 2000 \mathrm{~m}$ depth) and a rotation period of $\sim 3.5$ days; (iii) from May to September the eddy rotated clockwise without a significant net movement and from October to January the net movement was southeastward.

The interannual variability of the presence/absence of the $4^{\circ} \mathrm{W}$ eddy has been related to the inflow of the poleward winter slope flow off the northern Spain (Navidad). This is an extension, along the Cantabrian coast, of the Iberian Poleward Current (IPC). As with other Eastern Poleward Currents, which are driven by density forcing, the IPC is associated with eddies at the oceanic boundaries, generated as a consequence of the separation or evolution of perturbations in the flow regime. In the western Iberian coast, the IPC is responsible for the generation of migratory eddies (Pingree and Le Cann, $\underline{1993}$ ) and of persistent anticyclones that remain trapped in the lee of topography (Peliz et al., 2003). When the IPC/Navidad enters the Cantabrian coast, where the slope is parallel to the dynamic height contours, this current passes to a decaying phase (Pingree and Le Cann, 1990; Pingree et al., 1999; Le Cann and Serpette, 2009). Le Cann and serpette (2009) observed that the opposing effects of the dynamic forcing along the Cantabrian slope could create instabilities in the slope currents. The limit between both effects is around $4^{\circ} \mathrm{W}$ : positive (negative) wind stress curl east (west) of this position induce (restrain) the poleward direction of the slope current. These authors also argued that the alongshore slope current decay (and the subsequent instabilities) could be also induced by an offshore currents migration. Pingree et al. (1999) considered that the current decayed due to inertial overshoot relating to slope topography and loss of slope current transport and continuity. East of $5^{\circ} \mathrm{W}$, the major change of the coast and slope orientations, together with the presence of some steep bathymetric irregularities (submarine canyons of Torrelavega, Capbreton and Cap Ferret and the Landes Plateau), can be expected to significantly affect the shelf/slope circulation by adding complexity to the regional ocean circulation. Indeed, the area between Capbreton and Cap Ferret canyons is known for its intense mesoscale activity (Le Cann and Serpette, 2009). 
Subsurface water masses $(>200 \mathrm{~m})$ on the Cantabrian slope show a maximum temperature between mid-September and mid-March, when Navidad is developed (Pingree, 1994). A monitoring of this current during the last three decades show that a marked Navidad was developed 1/3 of the years (Garcia-Soto and Pingree, 2012) and specifically during the last decade it was observed in 2001, 2003, 2007 and 2010. The $4^{\circ} \mathrm{W}$ eddy is not generated when Navidad is confined to the western Cantabrian coast, but it can be observed when this winter flow is extended along the main part of the Cantabrian coast (Pingree and Le Cann, 1992a). Thus, between 1979 and 2000, this type of eddy was observed during years of strong Navidad: 1982, 1989, 1990 and 1996 (Garcia-Soto et al., 2002).

Two possible hypotheses coexist concerning the generation of the $4^{\circ} \mathrm{W}$ eddy. On the one hand, the generation area of the quasi-stationary eddy monitored in 1990 appeared to be the Cap Ferret canyon (Pingree and Le Cann, 1992a), where the eddy was observed fully developed in April. Nevertheless, the lack of observations before that month did not permit corroboration of this hypothesis. On the other hand, in a subsequent study, the generation was observed from an offshoot of Navidad near Capbreton canyon (Garcia-Soto et al., 2002).

Besides the effects that mesoscale eddies have in the ocean from a physical point of view, they also play an important role in the ocean biology. Bakun (1996) classified this biological influence into three processes (ocean triad): enrichment, concentration and retention. An example of enrichment is the upwelling mechanism induced in the interior of cyclonic eddies, in which cold water masses with nutrients are transported to the photic zone, generating phytoplankton blooms. In turn, frontal zones in the border of the eddy favour the concentration of passive or weakly swimming organisms (Agostini and Bakun, 2002). In the case of SWODDIES a cooling of the core surface waters does not indicate an upwelling event; since the doming of the seasonal thermocline (late spring or summer) results in a cooling of the surface waters of the SWODDIES' core. Garcia-Soto et al. (2002) analysed the biological response (focused on phytoplankton and primary production) within this type of structure. With regard to the retention process, eddies can retain the planktonic species located in the water masses at the time and place where these structures are generated (Bakun, 2006). A relationship between eddies and the survival of fish larvae has been observed (Bakun, 2006), for example in anchovies (Nakata et al., 2000; Holliday et al., 2011). Some studies, focused on the Bay of Biscay, relate particular distributions of hake larvae (Sánchez and Gil, 2000) and anchovy (Irigoien et al., 2008) to the presence of eddies. This last study suggests that anchovy larvae can be retained in the core of eddies generated in the spawning area.

Obtaining a more complete knowledge of the dynamics of these eddies is a requirement for the study of their biological influence in this ocean region. For this reason, a dedicated and comprehensive analysis of the properties of these structures appears to be necessary in order to better characterize them. Up to now, $4^{\circ} \mathrm{W}$ quasistationary eddies have been studied either by looking for the presence of them from 
satellite images, or by analysing the characteristics of a specific structure. The objectives of the study are to analyse statistically the interannual recurrence and the persistence, during the year, of $4^{\circ} \mathrm{W}$ quasi-stationary eddies and to give new information concerning the generation, 3D characteristics and decay of these structures. The interannual recurrence and persistence of the $4^{\circ} \mathrm{W}$ eddies is analysed in Section 3.1. An analysis of a specific year (2008) is shown in Section 3.2.1. Finally, an eddy tracking method applied to the outputs of a numerical model, permits study of the vertical characteristics of some eddies generated in the southeastern Bay of Biscay; as well as monitoring the trajectory followed by these structures on a continuous daily basis, from their birth to their decay (Section 3.2.2).

\section{Data and methods}

To carry out this study, independent and complementary in situ and remote measurements are used, as well as outputs from eddy-resolving numerical simulations. Two different periods are considered, depending on the objective. Section 3.1 describes an interannual analysis by using data from satellite altimetry and from the numerical model, covering the period January 2003 to December 2010. In Section 3.2., the study is focused on the generation and evolution of a specific $4^{\circ} \mathrm{W}$ quasi-stationary eddy, during a target year and from remote sensing, in situ data and simulations. In this case, 2008 was chosen due to the highest availability of cloud-free satellite images during the key dates. In the following subsections, the different data sets, together with the eddy tracking method, are described.

\subsection{Remote sensing data}

Daily images of oceanographic variables, derived from visible and infrared sensors on board satellites, allow synoptic observation of mesoscale processes with surface signals. In order to look for surface signals of the $4^{\circ} \mathrm{W}$ eddies, cloud-free Sea Surface Temperature (SST) and Chlorophyll-a (Chl-a) concentration images covering the Bay of Biscay were selected for 2008. Level 2 SST images were derived from the AVHRR sensor series $(\sim 1 \mathrm{~km}$ resolution); whilst, level 2 Chl-a images were obtained by MERIS ( $\sim 1 \mathrm{~km}$ resolution). Unfortunately, the prevailing meteorological conditions of the area of study do not permit acquisition of continuous cloud-free SST and Chl-a images.

These data sets were then complemented with altimetry data. The altimetry data used were weekly maps of Sea Level Anomaly (SLA) and Geostrophic Current Anomaly (GCA) (altimetry product: global-delayed time-updated and merged SLA provided by SSALTO/DUACS), which have a $0.3^{\circ}$ latitudinal and longitudinal resolution. These maps are constructed from along track data obtained by different satellites, by applying a suboptimal objective analysis (Le Traon et al., 1998; Ducet et al., 2000). Since the recovery of mesoscale structures significantly improves when combining data from several altimeters (Pascual et al., 2006), data provided by the maximum number of satellites available for every period of time were selected. For 2003-2010 the 
measurements were obtained from different combinations (depending on the date) of at least 3 altimeters (TOPEX/Poseidon, GFO, Jason-1/2, ERS-2 and ENVISAT).

The SLA is the time-variable part of the Sea Surface Height (SSH), which in turns is the sea surface height above a reference ellipsoid. The SLA is estimated by removing from instantaneous measurements of the sea level, a 7 year mean of the $\mathrm{SSH}$, the so called Mean Sea Surface (MSS). This way of computing the variability of the ocean circulation is an alternative to the most straightforward way to extract dynamic information from altimetry; that is, the calculation of the SLA from a Mean Dynamic Topography (MDT). The MDT is the sea surface from the geoid, and represents the permanent part of the ocean circulation. Nevertheless, the centimetric accuracy of the geoid at short space scales $(\mathrm{O}(100 \mathrm{~m}))$, needed to resolve the spatial scales obtained from the altimetry, is not reached at the present time (Rio et al., 2011). Recent studies have demonstrated the improvement of adding the MDT to the SLA, in order to analyse the major ocean currents (Rio et al., 2011). Nevertheless, in this study SLA instead of ADT has been used due to the small spatial scale of the oceanographic structure analysed. A first comparison of the SLA with SST and Chl-a maps and in situ measurements, indicates that the derived geostrophic currents adjust better to the analysed mesoscale structure.

The main handicap of the selected data set is that their quality near the coast is significantly worse than in the open ocean, due to (i) insufficient sampling; (ii) the corruption of radiometer-altimeter waveforms as a consequence of the land contamination; and finally, (iii) the inadequacy geophysical corrections (Bouffard et al., 2008). Therefore, the altimetry analysis in this study will be focused on the processes observed over the abyssal plain.

Eddy Kinetic Energy (EKE) has been estimated from the zonal $\left(u_{g}\right)$ and meridional $\left(v_{g}\right)$ component of the geostrophic currents, assuming geostrophic balance and isotropy:

$$
E K E=\frac{1}{2}\left(u_{g}^{2}+v_{g}^{2}\right)
$$

\subsection{In situ data}

Data from drifters deployed within the Bay of Biscay for studying the surface circulation (Charria et al., 2011), were processed in order to select those sampling the $4^{\circ} \mathrm{W}$ eddies. The selected drifter was deployed during the CAROLS 2007 campaign. It had a surface float linked to a long ( $10 \mathrm{~m}$ long $\times \sim 1 \mathrm{~m}$ wide) holey sock drogue by a thin $(\sim 5$ $\mathrm{mm}$ ) cable and centred at $15 \mathrm{~m}$ depth. The position was transferred by an ARGOS localisation system.

Hourly ocean current measurements from AGL and Matxitxako oceano-meteorological buoys, moored over the slope in 2850 and $550 \mathrm{~m}$ water depth, respectively, were also processed (see location in Fig. 1). For the AGL buoy, data are acquired from a downward looking $300 \mathrm{kHz}$ ADCP, measuring currents over the upper $100 \mathrm{~m}$ of the 
water column. A downward looking $150 \mathrm{kHz}$ ADCP at the Matxitxako buoy measures currents over the upper $200 \mathrm{~m}$ of the water column.

\subsection{Modeled data}

Numerical simulations from a hydrodynamic model were processed, in order to investigate on the one hand, the generation, evolution and decay of the $4^{\circ} \mathrm{W}$ eddies and on the other hand, their vertical characteristics. The hydrodynamic model used to determine currents and temperature fields for the study area was the Regional Ocean Modeling System (ROMS). The numerical aspects of ROMS are described in detail by Shchepetkin and McWilliams (2005). For the simulations, two 1-way nested spatial domains were used (Fig. 1): a coarser domain covered the Bay of Biscay with a $6.6 \mathrm{~km}$ horizontal resolution; an inner domain covered the southeastern corner of the Bay of Biscay with a $2.2 \mathrm{~km}$ horizontal resolution. The vertical resolution, bathymetry, the conditions applied to the open boundaries and the tidal forcing are specified in Ferrer and Caballero (2011).

The surface forcing inputs used for the model were the 6-hourly and $\sim 2^{\circ}$ horizontal resolution reanalysis data provided by National Center for Environmental Prediction (NCEP). The variables used from this database were: air temperature and relative humidity at $2 \mathrm{~m}$ height, precipitation rate, short-wave and long-wave radiation, and wind stress at $10 \mathrm{~m}$ height. The external conditions were obtained from the Estimating the Circulation and the Climate of the Ocean (ECCO) global data assimilation product $\left(1^{\circ}\right.$ and 10-day spatiotemporal resolution), which were also used for establishing the initial conditions. For the inner grid, the boundary conditions were provided by the results obtained from the coarser grid.

Using the aforementioned forcing and boundary conditions, a simulation covering the period 1998-2010 was carried out with ROMS model in order to explore the eddy dynamics in the inner domain. After a spin-up period of two years of simulation, the model exhibited no significant temporal drift. The model solution, starting from rest, adjusted rapidly to the initial stratification. The level of kinetic energy increased following the growing eddy activity during the two first years of simulation, in which the model nearly reached equilibrium. After the spin-up period, the kinetic energy stayed particularly stable, oscillating quasi-periodically around an equilibrium value. This is in agreement with other simulations carried out with ROMS model in different regions of the world ocean (e.g. Penven et al., 2001; Marchesiello et al., 2003).

\subsection{Eddy tracking method}

The WATERS wavelet-based utility program (Doglioli et al., 2007), applied to the surface geostrophic velocity fields provided by satellite data and the numerical simulations, was used in order to identify mesoscale eddies. The wavelet analysis consists of the 2D decomposition of maps into wave packets (position localized in space) and the subsequent reconstruction and identification using the first (most energetic) wavelets (Doglioli et al., 2007; Rubio et al., 2009; Dencausse et al., 2010). The wavelet-based tracking is applied to the relative vorticity fields derived from the 
SLA given by altimetry and simulations (free surface height). This 2D approach allows quantitative estimates of eddy distribution, polarity and size. In addition, it permits comparison of the model eddy activity with that observed by satellite altimetry.

The results of this wavelet analysis are dependent on some predefined parameters (Souza et al., 2011). First, the number of spectral coefficients kept for signal reconstruction (only the wavelets with the largest coefficients are kept) is critical for the analysis. Since the values of relative vorticity characterizing mesoscale structures in observations and simulations are comparable, the same number of spectral coefficients is kept for both data sets. As suggested by Doglioli et al. (2007), the best results are obtained with percentages around $10 \%$ (higher percentages increase noise in pattern recognition and lower percentages involve losing part of the mesoscale signal). Another strategy used to minimize the mesoscale signal lost in the decomposition is to reduce the search area also to the southeastern Bay of Biscay (see later Fig. 4), since eddies in this area are relatively weak compared with others further northwest. After the eddy area is obtained from the wavelet analysis, the eddy centre is defined as the grid point inside the eddy contours, which shows the maximum value of absolute relative vorticity. The precision of the centre position corresponds, consequently, to the grid spacing of the data or the model. The diameter of the eddy is calculated as the average of the zonal and meridional diameters of the eddy area and it is given as a mean diameter. The eddy centre is defined as the grid point of local maximum of absolute relative vorticity, over the eddy area (defined through the wavelet analysis); and the zonal and meridional diameters are given by the zonal and meridional distances between the eddy centre and the endpoints of the structure (Doglioli et al., 2007). Then, the differences between the zonal and meridional diameters, with respect to the mean, are used as indicators of the error in mean diameter estimation and give an estimate of the degree of deformation of the eddy. Finally, a cut-off criterion, based on eddy size, is applied at the identified structures (Doglioli et al., 2007): only eddies with diameters over $80 \mathrm{~km}$ are kept for both satellite altimetry and simulations, in order to be consistent with the expected resolution of the altimetry maps.

In the estimation of the trajectories of the eddies, the criteria used to join an eddy detected at time $t$ to an eddy detected at time $t-1$ is based on a search radius $(r)$ : two eddies with the same polarity are linked by a trajectory if their respective centres are separated by a distance lower than $r$. Taking into account the expected eddy translation velocities in the area and considering the low temporal resolution of the SLA maps (weekly) compared to the simulations (daily), $r$ is set to $80 \mathrm{~km}$ for the altimetry and $30 \mathrm{~km}$ for the simulations. Finally, only eddies with lifetimes over 5 weeks are kept; eddies with shorter lifetimes are disregarded in order to avoid other non-coherent structures and artefacts in the satellite altimetry, linked to interpolation errors.

The 3D version of the wavelet-technique analysis was applied to the simulations, with the aim of monitoring some selected structures and illustrating their vertical characteristics. In comparison to the $2 \mathrm{D}$ approach, for the $3 \mathrm{D}$ analysis slightly different criteria were applied. First, detected structures with shorter diameters (up to $30 \mathrm{~km}$ ) are 
also kept to allow the tracking of the eddy from its formation to its decay. In the estimation of the trajectories of the eddies, the criteria used to join an eddy detected at time $t$ to an eddy detected at time $t-1$, is that the surface eddy centre at the time $t$ contains the eddy centre (of same polarity) determined at time $t-1$. This criterion avoids using a fixed radius and is more efficient at tracking the eddy, during its generation and decay. Finally, for the wavelets decomposition a moving search area, whose centre at time $t$ is derived from the centre of the tracked structure at the time $t-1$, is applied for allowing longer tracking. For successive time steps, the wavelet analysis is used every $20 \mathrm{~m}$ in depth until the eddy signal is lost.

\section{Results}

\subsection{Anticyclonic structures during 2003-2010}

In order to investigate whether the $4^{\circ} \mathrm{W}$ anticyclonic eddy is generated on a yearly basis, monthly climatologies of SLA and GCA have been calculated, within the period 2003-2010. As can be observed in Figure 2, there is a significant seasonal variability around $44^{\circ} 20^{\prime} \mathrm{N}-4^{\circ} \mathrm{W}$. Between October and January a cyclonic circulation dominates the area; this cyclonic circulation, during autumn and winter, has been observed in previous studies (Garcia-Soto, 2004). In February, there is a regime change and an anticyclonic circulation begins to appear in the area. This circulation reversal reflects the seasonal cycle of the slope current as a consequence of the SOMA effect (September/October-March/April, with a variability of \pm 1 month); with a winter poleward and summer equatorward flow of the slope current (Pingree, 1994). In March and mainly in April, a closed anticyclonic structure develops, which remains near this position until September. The anticyclonic structure appears to be confined to the south by the coast, to the west by Le Danois bank, and Torrelavega canyon, to the east by the Landes Plateau and to the northwest by the Jovellanos seamount.

In order to show the recurrence and persistence of the structure in this area, observational and model results were examined using the wavelets $2 \mathrm{D}$ tracking method and compared to what was observed by-eye in monthly means maps of SLA and GCA (Fig. 3). The wavelets method was applied to weekly SLA maps and to daily ROMS outputs, following the approximations described in Section 2.4. Figure 3 summarizes the periods when the structure was observed in the different data sets and analysis methods. Despite the limitations of the different data sets and the wavelet analysis, the comparisons show the ability of the model to reproduce this structure on 6 of the 8 analysed years. The simulated structures have similar characteristics to those observed in the altimetry and SST/Chl-a images (in terms of horizontal dimensions and gradients, see Section 3.2). Since the model is not constrained by data assimilation, the quantitative comparison with observations, in terms of mesoscale turbulence or through point-to-point comparisons, is avoided. From the comparison of trajectories and lifetimes, the model reproduces the $4^{\circ} \mathrm{W}$ eddy at approximately the same position as in the observations and during similar periods for most of the years, excepting 2005 and 2009; in these years, the eddy in the simulations is generated in February- March, 
while it is observed around April-May in the altimetry. Excepting 2010, the duration of the simulated eddies is shorter. The simulated eddies are observed to strongly interact with other energetic structures; as well as, weaken and drift off of the study area or die, after two or three months of remaining quasi-stationary around Torrelavega canyon.

As explained before, the $4^{\circ} \mathrm{W}$ eddies are generated in years of strong Navidad and this has been exceptionally developed during the last decades. This trend of Navidad could be related to the yearly development of the $4^{\circ} \mathrm{W}$ eddies, during 2003-2010. Increasing north component of the wind stress along western Iberia favors the IPC development; whilst, westerly to southwesterly winds in the north Spanish shelf enhance the Navidad flow (Pingree, 1993). Thus, the generation of the $4^{\circ} \mathrm{W}$ eddies are related to the wind regime in western and northern Iberia, during the previous winter: e.g. years as 2007 with early signal of $4^{\circ} \mathrm{W}$ eddy in the altimetry maps (Fig. 3) have a previous winter (2006/2007) with a prevalence of westerly to southwesterly winds off northwestern Iberia (García-Soto \& Pingree, 2012).

The trajectories of the 8 anticyclonic eddies tracked by the wavelet method, applied to ROMS data (whose lifetimes are shown in Figure 3), are plotted in Figure 4a. From the eddy tracking results, 6 of them are first detected between Capbreton and Torrelavega canyons. Two eddies are first detected further north, on the abyssal plain and in Cap Ferret canyon. In the case of this last eddy, the visual examination of model fields suggests that its origin is also in the vicinity of Torrelavega canyon. However, several interactions with other structures present in the area (which lead to abrupt changes in the drift velocity and modification of the eddy vorticity), during the first weeks of its lifetime, made the automatic tracking from its birth difficult. The tracking is not set up until the eddy reaches Cap Ferret canyon, where the eddy intensifies and its vorticity is less affected by the interactions with other eddies. With regard to the position of the last detection of these eddies, three of them disappear near the generation position, inside the area limited by the Landes Plateau, Capbreton and Torrelavega canyons and Jovellanos seamount. The eddy generated in February 2008 is observed to drift westwards at the end of its lifetime, disappearing west of $4^{\circ} \mathrm{W}$ some days later; other three eddies disappear at the north of the domain. Although the tracking of eddies is possible in altimetry (the wavelet decomposition applied to the interpolated SLA fields allows an identification of an eddy centroid at each time-step), the spatial and temporal resolution of altimetry data does not provide accurate positions for this centroids. Moreover, since the net displacement of the structures is relatively small, the trajectories of eddies detected on SLA maps are not examined; and direct comparison with the higher resolution numerical data is not performed. However, the eddy census done using the automatic 2D eddy tracking for eddies with diameters over $80 \mathrm{~km}$ shows a higher concentration of anticyclonic eddies southeast of the Jovellanos seamount and also northwest of this topographic feature (Figure $4 b$ ), which is in good agreement with model results (Figure 4c).

The EKE follows a seasonal cycle in the southeastern Bay of Biscay as a result of the eddy activity. In the case of the EKE for the whole Bay of Biscay, the maximum EKE is 
observed in December-January, whilst the minimum is reached in September (Caballero et al., 2008). With the aim of analysing the seasonal cycle of the EKE in the southeastern Bay of Biscay area, where the anticyclonic eddy is observed, monthly EKE maps have been processed from altimetry and ROMS maps (not shown). Despite the different spatial resolution of both data sets, EKE maps show a good qualitative agreement in terms of spatial distribution and seasonal variability of the energy. A maximum of EKE is observed around the Torrelavega canyon for both data sets in the months from April to August, although slightly displaced to the south west for the model results. However, EKE energies are significantly lower in the altimetry data. This was expected due to the lower resolution and the filtering applied to the altimetry data, which has been shown to result in a decrease of the energy level associated with the smallest scale variability resolved (below $100 \mathrm{~km}$ ) (Dussurget et al., 2011). In order to isolate only the EKE signal due to the $4^{\circ} \mathrm{W}$ eddies, a common area, where both data sets present maximum EKE associated with this structure, has been defined. Monthly EKE climatologies have then been spatially averaged for this common area (Fig. 5). This Figure shows that the EKE, estimated from altimetry maps, has a maximum in May-June. In July the EKE begins to decrease until October, when the minimum EKE is reached. The evolution of the EKE, derived from ROMS outputs, is similar. The maximum EKE is reached in June, and after this month it decreases until December, when the minimum is reached. The maximum EKE derived from ROMS outputs are close to the mean KE $\left(76 \mathrm{~cm} \mathrm{~s}^{-2}\right)$, resulting from the tracking of an Argos buoy, deployed in the southern Bay of Biscay from April to October 1992 (Pingree, 1994). The seasonal pattern of the EKE in the study area, was not observed in previous studies focused on the whole Bay of Biscay (Caballero et al., 2008), where the maximum EKE was observed in December-January. The EKE in this reduced common area, appears to be dominated by the presence/absence of the $4^{\circ} \mathrm{W}$ anticyclonic quasistationary eddy and shows maximum values in May-June.

\subsection{Analysis of a quasi-stationary anticyclonic eddy for a target year}

A detailed analysis for a target year (2008) has been done with two objectives: (i) to study in-depth the characteristics of this anticyclonic eddy, through its surface signal; and (ii) to give evidence for its generation near Capbreton canyon and of its permanence in the proximity of the generation area over several months.

This Section is organized as follows. First, the results from the processing and analysis of data and images, from different sources and for the target year are shown. Afterwards, with the objective of studying the 3D characteristics of the structure, results are presented from the eddy tracking method applied to ROMS simulations.

\subsubsection{Monitoring of the anticyclonic eddy from different observational data}

A warm surface tongue of $>15.8^{\circ} \mathrm{C}$, confined between the coast and the $200 \mathrm{~m}$ isobath, was observed on 19 January 2008 in the SST-GCA satellite derived image (Fig. 6a, a white square frames part of this warm tongue). A similar feature was observed in the 
area on 29 November 2006 by Le Cann and Serpette (2009). Figure 6a also shows a meandering of this tongue near $43^{\circ} 42^{\prime} \mathrm{N}-3^{\circ} 30^{\prime} \mathrm{W}$. The offshore direction of the slope current has been associated with the alongshore decay of this current (Pingree and Le Cann, 1990; Pingree et al., 1999; Le Cann and Serpette, 2009). The GCA superimposed on the SST image does not show this surface current. The currents measured by the AGL buoy show a regime change around 13 January, when the currents change from a southeastward to a northeastward direction (Fig. 7). This direction change is not observed by the Matxitxako buoy, located to the southeast of the AGL buoy (Fig. 1). The SST-GCA image corresponding to 26 January (Fig. 6b) shows how the warm tongue continues meandering. The northeastward direction of the current at this date is also observed by the AGL buoy, whilst the currents move westward at Matxitxako buoy. The following cloud-free SST-GCA image, corresponding to 5 February, shows a warm core $\left(\sim 15.9^{\circ} \mathrm{C}\right)$ eddy centred around $44^{\circ} 10^{\prime} \mathrm{N}-3^{\circ} 30^{\prime} \mathrm{W}$ (Fig. 6c). The GCA superimposed on the image indicates that it corresponds to an anticyclonic eddy, though the altimetry locates the core of this eddy as slightly displaced to the west. This difference could be ascribed to the fact that the eddy is in its generation phase, not completely detached from the warm surface tongue and describing relatively fast changes; hence, the SLA map computed from the interpolation of the different tracks of the altimeters (obtained in different days) does not reflect exactly the centre of the structure. This structure is also observed in the SST-GCA images corresponding to 9 and 12 February (Figs. 6d and e, respectively), centred around the same position and with a temperature in the core $\sim 15.7^{\circ} \mathrm{C}$. The AGL buoy shows the northwestward currents of the eddy periphery during 12 February. On 17 February, the warm core observed in the SST-GCA image, is centred around $44^{\circ} 20^{\prime} \mathrm{N}-3^{\circ} 30^{\prime} \mathrm{W}$ (Fig. 6f).

During March, there are not enough cloud-free SST images for observing the evolution of this anticyclonic eddy. 11 March a gale lashed the study area. This type of events usually produce a mixing of the surface water masses; thus, the surface water mixing induced by the gale, can be the reason why the only two SST images processed (not shown) do not show an evident signal of the eddy. Nevertheless, the SLA-GCA measured by the altimetry for this month indicates the presence of this eddy at around $44^{\circ} 10^{\prime} \mathrm{N}-3^{\circ} 30^{\prime} \mathrm{W}$ (Fig. 8a). In the SST-GCA image of 5 April (Fig. 8b) the warm water tongue appears on the Cantabrian shelf-slope and along the French shelf, up to $44^{\circ} 30^{\prime} \mathrm{N}$ latitude. The measurements from the Matxitxako buoy indicate that the slope current flows northwestward. The measurements of the eddy periphery by the AGL buoy are consistent with an anticyclonic circulation indicated by the GCA centred at $44^{\circ} 10^{\prime} \mathrm{N}-3^{\circ} 40^{\prime} \mathrm{W}$. The core of the anticyclonic eddy continues to be warmer than in the periphery; but comparing to the eddy observed in February, the temperature in the core is lower $\left(\sim 13.2^{\circ} \mathrm{C}\right)$. A decreasing in SST is observed in the whole study area, when comparing Figures 6c-f with Figure 8b; this indicates that from February to April there has been a fall in SST, within the whole study area and not only in the core of the eddy.

The Chl-a map of 15 April (Fig. 8c) shows that the concentration of this pigment in the core of the anticyclonic structure is lower than in the periphery. To the south of the 
anticyclonic eddy, the generation of a cyclonic structure is observed. The moored buoys indicate a southeastward direction of the slope current. 10 days after, the new dipole, with the anticyclonic eddy in the northeast, is completely developed (Fig. 8d). Unlike the anticyclonic eddy, the Chl-a concentration is higher in the core than in the periphery. This pattern in the Chl-a distribution of the surface signal on the anticyclonic and cyclonic eddies is due to the shallower depth of cyclonic eddies, in comparison with anticyclones, which favours an earlier start of the spring bloom (García-Soto et al., 2002). The GCA vectors superimposed on the image show the circulation around the anticyclonic eddy. Nevertheless, the cyclonic structure is not observed in the altimetry, probably due to the smaller size of the structure and to the proximity to the coast. The trajectory of the drifter for the period between 10 days before and 10 days after the date of the image, describes a complete anticyclonic gyre, which indicates that the drifter is moving around the anticyclonic eddy. The currents directions measured by the moored buoys are different for this date: southwestward for Matxitxako buoy and northeastward for AGL buoy. In addition, the current intensity is notably higher for the last one.

On 1 May, a remarkable Chl-a concentration rise is observed (Fig. 8e). There is a tongue of water coming from the southeast, advecting Chl-a to the dipole that is centred around $44^{\circ} 15^{\prime} \mathrm{N}-3^{\circ} 30^{\prime} \mathrm{W}$ (anticyclone) and $44^{\circ} \mathrm{N}-3^{\circ} 45^{\prime} \mathrm{W}$ (cyclone). The drifter trapped by the eddy continues to describe an anticyclonic circulation. The SST-GCA image, corresponding to 4 days after (Fig. 8f), shows that water mass in the core of the anticyclonic eddy is, now, colder than in the periphery. Despite the change in the surface signal of the structure, since the SST in the core of the eddy is identical to that observed on 5 April $\left(13.2^{\circ} \mathrm{C}\right)$, it is assumed that the SST signal corresponds to the same structure. Until May the SST in the core is higher than in the periphery, since the water masses in the core are those from a slope current with a higher SST than the surrounding water masses. The change of the SST horizontal gradient from May on is due to the different behaviour on the doming of the seasonal thermocline inside and outside the anticyclonic eddy; and has been observed in previous studies (e.g. Pingree and Le Cann, 1992a; Pingree, 1994). This change occurs when a significant increase and annual maxima (May-June) of EKE is observed in the study area (Fig. 5). In the Section 3.2.2 an example of the doming of the thermocline in the core of the eddy and based on simulations, is shown (Fig. 12a). The signal of the dipole continues being clear in the Chl-a images, with a higher Chl-a concentration in the core (periphery) than in the periphery (core) for the cyclone (anticyclone), centred around $44^{\circ} 10^{\prime} \mathrm{N}-4^{\circ} \mathrm{W}$ $\left(44^{\circ} 20^{\prime} \mathrm{N}-3^{\circ} 30^{\prime} \mathrm{W}\right)$, on 7 May (Fig. 8g), and around $44^{\circ} 20^{\prime} \mathrm{N}-4^{\circ} 10^{\prime} \mathrm{W}\left(44^{\circ} 30^{\prime} \mathrm{N}-3^{\circ} 30^{\prime} \mathrm{W}\right)$ on 20 May (Fig. 8h). The drifter trajectory validates the interpretation made of the satellite observations, during the analysed period.

During June, the monthly SLA-GCA map indicates that there is an anticyclone around $44^{\circ} 30^{\prime} \mathrm{N}-3^{\circ} 30^{\prime} \mathrm{W}$ (Fig. 9a). The drifter continues spinning clockwise during June, near the centre of the anticyclone. On 8 July, the SST-GCA image shows a SST gradient at the position of the anticyclonic eddy described by the GCA vectors (Fig. 9b); the drifter continues to move clockwise around the cold core $\left(\sim 18.8^{\circ} \mathrm{C}\right)$ and the water masses 
around the AGL buoy describe a northwestward direction. On this date, as on 5 May (Fig. 8f), the core continues being colder than the periphery. From this date on, there is not surface signal of this structure in SST and Chl-a maps. But the anticyclone is observed both in SLA-GCA maps until at least 8 August and from the trajectory of the drifter, until around 10 August. After this date, the drifter leaves the eddy and is directed towards the Cantabrian coast (Fig. 9c).

\subsubsection{Characteristics of the simulated anticyclonic eddy}

As shown in Section 3.1, ROMS configuration used for this study is able to reproduce the $4^{\circ} \mathrm{W}$ eddies, with similar characteristics to those observed through satellite imagery and in situ data. Vertically, the simulated eddies have extensions between 2000 and $4000 \mathrm{~m}$ depth, which is in accordance with the vertical extension, $>2000 \mathrm{~m}$ depth, of the $4^{\circ} \mathrm{W}$ SWODDY observed by Pingree and Le Cann (1992b). Taking into account the qualitative similarities observed, three simulated anticyclones are tracked in time and described herein, with the main objectives of investigating their 3D characteristics and establishing hypothesis on their generation and decay.

During 2008, two anticyclonic eddies with similar characteristics are followed by the 3D version of the wavelet tracking utility. These two eddies are generated in February (hereinafter eddy FEB08) and May (hereinafter eddy MAY08) in the vicinity of Torrelavega canyon and are observed to remain trapped in this area for more than 7 weeks. Thus, for 2008, model results suggest that this type of structure could be recurrent during the year, being generated several times within the period from January to May-June. However, this is not the case for simulations of other years, for example 2004 (eddy MAR04), 2009 and 2010, where similar anticyclones are generated only once a year and remain quasi-stationary near the generation area over a longer period.

FEB08 eddy is generated at the beginning of February in the vicinity of the Torrelavega canyon, around $44^{\circ} \mathrm{N}-4^{\circ} \mathrm{W}$. It is tracked over 53 days and remains quasi-stationary until mid of March, when it starts to drift westwards (Fig. 10a). The SST map with depthintegrated Currents (C) superimposed, derived from ROMS and corresponding to 6 February (Fig. 10b), shows a warm core anticyclonic structure centred around $44^{\circ} 10^{\prime} \mathrm{N}$ $3^{\circ} 40^{\prime} \mathrm{W}$. This represents a similar situation to the one observed in the satellite data SST-GCA maps from 5 to 17 February; during this period, the warm core is centred around $44^{\circ} 20^{\prime} \mathrm{N}-3^{\circ} 30^{\prime} \mathrm{W}$ (Figs. $6 \mathrm{c}-\mathrm{f}$ ) and a warm water tongue is observed along the shelf/slope (Figs. 6e and f). On several occasions the FEB08 eddy is observed to interact with other mesoscale structures. For instance, on 28 February and 4 March the structure interacts with two cyclones, forming a dipole but does not experience major changes in its structure or drift velocity (Fig. 11). The main diameter remains around 40-60 km for most of its lifetime. Stronger deformation is observed at the end of its lifetime, when the eddy is squeezed after interacting with cyclonic structures. It dissipates around 15 March, over abyssal depths $(\sim 4000 \mathrm{~m})$. The drift velocities shown by the eddy during its lifetime are under $5 \mathrm{~cm} \mathrm{~s}^{-1}\left(\sim 4 \mathrm{~km} \mathrm{day}^{-1}\right)$. Vertically, the detection algorithm loses its anticyclonic signal at $\sim 2500 \mathrm{~m}$ depth, except for several days around 20 February, when it is detected to $3000 \mathrm{~m}$ depth (Fig. 11). Marked changes in 
the vertical extension of the eddy are observed during the first part of its lifetime, coinciding with its passage over shallower floor; this could indicate that the eddy is interacting with the bathymetry. From 20 to 29 February, the eddy drifts northwards following the main axis of the submarine canyon. After 29 February, the eddy is located over deeper regions and its vertical extension is gradually reduced (from $2000 \mathrm{~m}$ to $1000 \mathrm{~m}$ depth). At the beginning of March the eddy starts to drift westwards, passing over the Jovellanos seamount and disappears west of Torrelavega canyon some days later.

MAY08 eddy is first detected the second week of May, around $44^{\circ} \mathrm{N}-4^{\circ} \mathrm{W}$, in the vicinity of the Torrelavega canyon (Fig. 10c). It is tracked over 54 days and observed to remain quasi-stationary between $4^{\circ} \mathrm{W}$ and $3.5^{\circ} \mathrm{W}$, disappearing on 27 June some tens of kilometres to the east of its generation location. The SST-C map simulated by the model indicates the presence of this eddy slightly displaced to the southeast (Fig. 10d), from the position observed in the monthly SLA-GCA map (Fig. 9a, anticyclone located around $44^{\circ} 30^{\prime} \mathrm{N}-3^{\circ} 30^{\prime} \mathrm{W}$ ). As in the observations (SST images corresponding to 5 May and 8 July, Figs $8 f$ and 9b, respectively), the simulated SST shows temperatures colder in the core than in the periphery. Figure $12 a$ represents a vertical section from the surface to $500 \mathrm{~m}$ depth of the potential temperature of the simulated eddy, and along the section of approximately $100 \mathrm{~km}$ shown in Figure $10 \mathrm{~d}$ and for the same date (8 July 2008). In this section, the centre of the eddy is located at approximately $50 \mathrm{~km}$ from the origin of the section. A core of water in the centre of the eddy extends from about 50 to $200 \mathrm{~m}$ depth, with a potential temperature between 12.5 and $13.5{ }^{\circ} \mathrm{C}$. There is a doming of the thermocline in the first 50 to 100 meters of core of the structure and a depression below $100 \mathrm{~m}$ depth. Similar sections were obtained from XBTs measurements of F90 and X91 SWODDIES located in the Bay of Biscay in 1990-1991 (Pingree and Le Cann, 1992a; Pingree and Le Cann, 1992ab). In addition, the vertical section of the simulated meridional component of the current along the same section and date (Fig. 12b), shows how the speed decreases from the western and eastern extremes to the core of the eddy, until the speed becomes zero on the central axis of the eddy. The meridional component of the current is positive (northward) in the western extreme of the eddy, whilst it is negative (southward) in the eastern extreme; this pattern shows the anticyclonic rotation extends to depths greater than $500 \mathrm{~m}$. The speed is maximum between 50 and $150 \mathrm{~m}$ depth; somewhat shallower than the maximum azimuthal flow measured in F90 and X91 SWODDIES ( 200 m). Surface speed is comparable to that of the drifter shown in Section 3.1; which moved at speeds of 3 to $24 \mathrm{~cm} \mathrm{~s}^{-1}$, between April and September 2008 (not shown). During its lifetime, this eddy has a diameter of around $50 \mathrm{~km}$ and interacts with other cyclonic and anticyclonic structures. This results in significant changes of its structure, and strong variability in the surface vorticity signal of this eddy (Fig. 11). As a consequence, we observe the diameter inferred from the wavelets analysis to change significantly during its lifetime. From 4 June, a significant increase of eddy diameter and of the error in the diameter determination is observed. This error depends on the difference of the diameter defined in both horizontal axes and; thus, it gives an estimate of the degree of deformation of the structure. On this date, there is also a slight increase of the drift 
velocity (which otherwise remains stable around $4 \mathrm{~cm} \mathrm{~s}^{-1}$ ), when the eddy starts to drift towards the east (shallower floor). The vertical extension of the eddy remains less than $2000 \mathrm{~m}$ depth until 6 June, when it increases to $3000 \mathrm{~m}$ within a few days. When the eddy encounters the Landes Plateau, around 15 June, it deviates to the south and disappears around two weeks later, over the upper part of the slope, off Cape Ajo.

Finally, to give an example of one of the long-lived and quasi-stationary eddies simulated by ROMS model in the study area, we describe the characteristics of eddy MAR04. This eddy was generated on 1 March 2004, also in the vicinity of the Torrelavega canyon, at $43^{\circ} 50^{\prime} \mathrm{N}-3^{\circ} 50^{\prime} \mathrm{W}$ (Fig. 10e). It is tracked over 121 days and observed to remain quasi-stationary in the area, describing an anticyclonic loop until its signal is lost on 30 June around the same position. The general anticyclonic displacement of the eddy centre around the Azores-Biscay Rise of the eddy analysed by Reverdin et al. (2009) was suggested to be due to a bathymetric beta-effect. MAR04 has a deeper structure than that observed previously in this Section, being detected down to 3000-3500 $\mathrm{m}$ depth, during the two central months of its lifetime. Over its lifetime, as in the case of the FEB08 and MAY08 eddies, its diameter ranges from 40 to $60 \mathrm{~km}$ and the azimuthal velocity is less than $20 \mathrm{~cm} \mathrm{~s}^{-1}$. The surface temperature signal of this structure corresponding to 18 March is shown in Figure 10f, when the eddy is located over the mouth of Torrelavega canyon. The warm core of the eddy has a similar temperature to that associated with the surface signal of the slope current and represents a positive anomaly of $0.1-0.2^{\circ} \mathrm{C}$, with respect to its periphery. From midMarch to the end of April, the eddy is located around $44^{\circ} 30^{\prime} \mathrm{N}-3^{\circ} 50^{\prime} \mathrm{W}$ and experiences the weakest drifting velocities (under $5 \mathrm{~cm} \mathrm{~s}^{-1}$ ). During this period, in a position limited to the west by the Jovellanos seamount, the eddy describes several small anticyclonic loops, resulting in very small net translation. This looping trajectory was also described by the MEDDY analysed by Paillet et al. (2002) and was related to the interaction with other MEDDIES and/or the interaction with deep seamounts. As occurs with eddies described previously, the MAR04 eddy interacts with other eddies, showing changes in diameter and intensity. During April it interacts with a cyclone at its southwest; then at the beginning of May, it interacts with a cyclone to its northwest, triggering a strong deformation of the eddy. It also forms a dipole with a cyclone located on its east side from 4 to 20 June. On 10 June the vertical extension of the eddy begins to decrease as it drifts southeastward towards the upper slope, where it disappears at the end of the month. During this period the vertical extension of the anticyclone is about $3000 \mathrm{~m}$, decreasing to $2000 \mathrm{~m}$ from 10 June. The depth of cyclones (during the period they interact with MAR04 eddy) ranges from 500 to $1000 \mathrm{~m}$, between half and a third that of the anticyclone; in addition, the diameters of the cyclones are around half the anticyclone's diameter. The higher volume of the anticyclone indicates the dominance of the anticyclone over the dynamics of the associated cyclones.

\section{Summary and conclusions}

The presence and recurrence of quasi-stationary $4^{\circ} \mathrm{W}$ eddies in the southeastern corner of the Bay of Biscay has been assessed for the period 2003-2010. Monthly 
climatological SLA and GCA maps show the presence of anticyclonic eddies centred around $44^{\circ} 20^{\prime} \mathrm{N}-4^{\circ} \mathrm{W}$, which remain quasi-stationary in the area for more than 6 months (from March-April to September). The presence of anticyclonic eddies in this area has been analysed, in detail, using an eddy tracking method applied to SLA maps and ROMS numerical simulations for the same years. The results obtained suggest that the $4^{\circ} \mathrm{W}$ eddies are recurrent structures, and that they can be observed in almost all years within 2003-2010. Also, and in spite of the differences among the data sets (in terms of temporal and spatial resolution) and of the limitations of the wavelet analysis, the agreement between simulations and observations is reasonably good. The model is able to reproduce structures similar to those observed in the SLA-GCA, SST and Chl-a images. The simulations suggest that most of the eddies originate in the vicinity of Torrelavega and Capbreton canyons and that they disappear near the generation position: inside the area limited by the Landes Plateau, Capbreton and Torrelavega canyons and Jovellanos seamount.

From the detailed analysis of an anticyclonic eddy from February to August 2008, it can be concluded that the eddy was generated in Capbreton canyon from a northward meandering of a warm slope current at the end of January and the beginning of February. There is a gap in March, when the eddy can be only observed in altimetry maps. The surface signatures of this eddy in terms of SST and Chl-a, and the time-lag in the doming of the thermocline inside the anticyclonic eddy, are consistent with those obtained for SWODDY-like eddies in previous studies. Both measurements and simulations suggest that these eddies have diameters around 40 to $60 \mathrm{~km}$ and low drift velocities. They are observed to interact with other eddies present in the area and to form dipoles with other cyclones over several weeks. The simulated anticyclones extend from the surface to more than $3500 \mathrm{~m}$ depth in some cases.

The $4^{\circ} \mathrm{W}$ eddies remain near the same position for weeks or months. As Pingree and Le Cann (1992a) concluded in their study, the $4^{\circ} \mathrm{W}$ eddies are trapped by the topography, to the west by the complex bathymetry between Le Danois bank and Torrelavega canyon and to the east by the Landes Plateau. In this contribution we suggest that the Jovellanos seamount (around $3500 \mathrm{~m}$ depth), located in $44^{\circ} 30^{\prime} \mathrm{N}$ $4^{\circ} 15^{\prime} \mathrm{W}$, could be the northwestern limit of the $4^{\circ} \mathrm{W}$ eddies. It is not clear if the topographic irregularity itself or the dynamical processes around it induces the eddy to be trapped. Nevertheless, according to the model simulations most of the eddies generated in Capbreton canyon are quasi-stationary. This is the case, for instance, of MAR04 eddy. This eddy remains around 4430' $\mathrm{N}-3^{\circ} 50^{\prime} \mathrm{W}$ over several weeks, describing small anticyclonic loops to the east of the Jovellanos seamount. However, the model also reproduces eddies that migrate northward or westward. In the latter case, the eddies pass over the Jovellanos seamount, some weeks after their generation. An example of this behaviour is FEB08 eddy, which passes over the Jovellanos seamount at the end of its lifetime, when its vertical extension is less that $2000 \mathrm{~m}$. Conversely, there must be some conditions under which eddies remain trapped near their point of generation. Numerical simulations in an f-plane showed that the interaction of a surface-intensified anticyclonic vortex with an isolated seamount 
was sensitive to the following factors: seamount radius and height, vortex-seamount distance, vortex radius and stratification (Herbette et al., 2003). Other factors, like eddy interactions with different topographic features or eddy-eddy interactions, could also play a role in determining whether or not eddies generated near Capbreton canyon migrate. How these factors contribute to the behaviour of the $4^{\circ} \mathrm{W}$ eddies near the Jovellanos seamount is an interesting issue that should be addressed in further studies.

Finally, several authors have discussed the origin of these structures (e.g. Pingree and Le Cann, 1992a, Garcia-Soto et al., 2002) and suggested that it is linked to the instabilities of the slope current near local topographic irregularities, as happens for other SWOODIES on the Cantabrian slope. Studying the specific conditions and the physical mechanisms that lead to the generation of these structures was outside the scope of this article and deserves further investigation. New observational evidence is given for the generation of one of these eddies from a meandering of the warm slope current in Capbreton canyon (Fig. 6). Simulations also suggest that $4^{\circ} \mathrm{W}$ eddy generation occurs in the vicinity of Torrelavega and Capbreton Canyons. However, they do not provide any example of $4^{\circ} \mathrm{W}$ eddy generation in the area of Cap Ferret canyon.

This paper is a step forward to other studies of mesoscale processes focused in the Bay of Biscay, since the results are the combination of in situ and remote sensing measurements, numerical modeling simulations and an eddy tracking method applied to altimetric data and to numerical simulation outputs. In this manner it has taken the advantages of all of them: the reliability of the in situ data, the coverage and high spatial resolution of the SST and Chl-a maps, the continuous sampling of the altimetry data, the 3D information of the models and the analytical way of monitoring eddies of the eddy tracking method, among others. This exercise of compiling different sources of data and methodologies in order to study a particular eddy can be extrapolated for studying other eddies in the world ocean.

\section{Acknowledgements}

This study has been undertaken with the financial support of the Spanish Ministry of Science and Innovation (National R\&D\&I Plan, ESTIBB CTM2009-12339 project) and the Department of Environment, Regional Planning, Agriculture and Fisheries of the Basque Government (Marco Program)). The work of A. Rubio was partially supported by a Torres Quevedo grant (Spanish Ministry of Science and Innovation, PTQ-08-0308447). The application of the wavelets-based eddy detection utility in the Bay of Biscay has been done in the framework of the French WASSCO project: "Application de Suivi de Structures Coherentes 3D dans des modèles de circulation océanique haute résolution MERCATOR et comparaison avec des données altimétriques" (GMMC MERCATOR program). We would like to thank all data providers in their effort to distribute oceanographic information: (i) NCEP reanalysis data provided by the NOAA/OAR/ESRL PSD, Boulder, Colorado, USA (http://www.esrl.noaa.gov/psd/); (ii) Consortium for Estimating the Circulation and Climate of the Ocean (ECCO) funded by 
the National Oceanographic Partnership Program; (iii) Altimeter products produced by Ssalto/Duacs and distributed by Aviso, with support from Cnes (http://www.aviso.oceanobs.com/duacs/); (iv) SST and Chl-a data produced and distributed by NERC Earth Observation Data Acquisition and Analysis Service (NEODAAS, http://www.neodaas.ac.uk/data/); (v) Augusto González de Linares (AGL) Moored buoy data, provided by the Instituto Español de Oceanografía (I.E.O.) (www.boya agl.st.ieo.es/); and (vi) Matxitxako buoy data belonging to Meteorology and Emergencies Directorate of the Basque Government. We would also like to thank Bernard Le Cann for his constructive observations, and Alicia Lavin and Daniel Cano for facilitating our use of data from the AGL buoy. This is contribution number 604 , of the Marine Research Division of AZTI-Tecnalia.

\section{References}

- Agostini, V.N., Bakun, A., 2002. "Ocean triads" in the Mediterranean Sea: physical mechanisms potentially structuring reproductive habitat suitability (with example application to European anchovy, Engraulis encrasicolus). Fish. Oceanogr. 11 (3), 129-142.

- Bakun, A., 1996. Patterns in the Ocean: Ocean Processes and Marine Population Dynamics. California, USA: University of California Sea Grant, San Diego, in cooperation with Centro de Investigaciones Biológicas de Noroeste, La Paz, Baja California Sur, Mexico, 323 pp.

- Bakun, A., 2006. Fronts and eddies as key structures in the habitat of marine fish larvae: opportunity, adaptive response and competitive advantage. Sci. Mar. 70 (S2), 105-122.

- Bender, L.C., DiMarco, S.F., 2008. Quality control and analysis of acoustic Doppler current profiler data collected on offshore platforms of the Gulf of Mexico. U.S. Dept. of the Interior, Minerals Mgmt. Service, Gulf of Mexico OCS Region, New Orleans, LA. OCS Study MMS 2009-010, 63 pp.

- Bernstein, R.L., Breaker, L., Whritner, R., 1977. California Current eddy formation: Ship, air and satellite results. Science 195, 353-359.

- Bouffard, J., Vignudelli, S., Cipollini, P., Menard, Y., 2008. Exploiting the potential of an improved multimission altimetric data set over the coastal ocean. Geophys. Res. Lett. 35, L10601, doi:10.1029/2008GL033488, 6 pp.

- Burkov, V.A., Pavlova, Yu. V., 1980. Description of the eddy field of the California Current. Oceanology 20, 272-278.

- Caballero, A., Pascual, A., Dibarboure, G., Espino, M., 2008. Sea level and Eddy Kinetic Energy variability in the Bay of Biscay, inferred from satellite altimeter data. J. Mar. Syst. 72 (1-4), 116-134. 
- Charria, G., Lazure, P., Le Cann, B., Serpette, A., Reverdin, G., Louazel, S., Batifoulier, F., Dumas, F., Pichon, A., Morel, Y., 2011. Surface layer circulation derived from Lagrangian drifters in the Bay of Biscay, J. Mar. Syst., doi:10.1016/j.jmarsys.2011.09.015.

- Chelton, D.B., Schlax, M.G., Samelson, R.M., de Szoeke, R.A., 2007. Global observations of large oceanic eddies. Geophys. Res. Lett. 34, L15606, doi: 10.1029/2007GL030812, 5 pp.

- Chelton, D.B., Schlax, M.G., Samelson, R.M., 2011. Global observations of nonlinear mesoscale eddies. Progr. Oceanogr. 91(2), 167-216, doi: 10.1016/j.pocean.2011.01.002.

- Cushman-Roisin, B., Beckers, J.M., 2011. Introduction to Geophysical Fluid Dynamics: Physical and Numerical Aspects. International Geophysics Series, 101 ( $2^{\text {nd }}$ Edition), Academic Press, 828 pp.

- De Miranda, A.P., Barnier, B., Dewar, W.K., 1999. On the dynamics of the Zapiola Anticyclone. J. Geophys. Res., 104(C9), 137-149.

- Dencausse, G., Arhan, M., Speich, S., 2010. Routes of Agulhas rings in the southeastern Cape Basin, Deep-Sea Res. I 57, 1406-1421, doi:10.1016/j.dsr.2010.07.008.

- Doglioli, A.M., Blanke, B., Speich, S., Lapeyre, G., 2007. Tracking coherent structures in a regional ocean model with wavelet analysis: Application to Cape Basin Eddies. J. Geophys. Res. 112, C05043, doi: 10.1029/2006JC003952, 12 pp.

- Ducet, N., Le Traon, P.-Y., Reverdin, G., 2000. Global high-resolution mapping of ocean circulation from TOPEX/Poseidon and ERS-1 and -2. Journal of Geophysical Research 105, 19477-19498.

- Dussurget, R., Birol, F., Morrow, R., De Mey, P., 2011. Fine resolution altimetry data for a regional application in the Bay of Biscay. Mar. Geodesy 34, 447-476.

- Egbert, G.D., Bennett, A.F., Foreman, M.G.G., 1994. TOPEX/Poseidon Tides estimated using a Global Inverse Model. J. Geophys. Res. 99 (C12), 2482124852.

- Ferrer, L., Caballero, A., 2011. Eddies in the Bay of Biscay: A numerical approximation. J. Mar. Syst. 87 (2), 133-144.

- Garcia-Soto, C., Pingree, R.D., Valdés, L., 2002. Navidad development in the southern Bay of Biscay: Climate change and SWODDY structure from remote sensing and in situ measurements. J. Geophys. Res. 107, 3118, doi: 10.1029/2001JC001012, $29 \mathrm{pp}$. 
- Garcia-Soto, C., 2004. 'Prestige' oil spill and Navidad flow. J. Mar. Biol. Assoc. U.K. 84, 297-300.

- Garcia-Soto, C., Pingree, 2012. Atlantic Multidecadal Oscillation (AMO) and sea surface temperature in the Bay of Biscay and adjacent regions. J. Mar. Biol. Assoc. U.K. 92(2), 213-234.

- Herbette, S., Morel, Y., Arhan, M., 2003. Erosion of a surface vortex by a seamount. J. Phys. Oceanogr. 33, 1664-1679.

- Holliday, D., Beckley, L., Olivar, P., 2011. Incorporation of larval fishes into a developing anti-cyclonic eddy of the Leeuwin Current off south-western Australia. J. Plankton Res. 33 (11), 1696-1708.

- Huppert, H., Bryan, K., 1976. Topographically generated eddies. Deep-Sea Res. 23, 655-679.

- Irigoien, X., Cotano, U., Boyra, G., Santos, M., Álvarez, P., Otheguy, P., Etxebeste, E., Uriarte, A., Ferrer, L., Ibaibarriaga, L., 2008. From egg to juvenile in the Bay of Biscay: spatial patterns of anchovy (Engraulis encrasicolus) recruitment in a non-upwelling region. Fish. Oceanogr. 17 (6), 446-462.

- Le Cann, B., Serpette, A., 2009. Intense warm and saline upper ocean inflow in the southern Bay of Biscay in autumn-winter 2006-2007. Cont. Shelf Res. 29 (8), 1014-1025.

- Le Traon, P.-Y., Nadal, F., Ducet, N., 1998. An improved mapping method of multisatellite altimeter data. Journal of Atmospheric and Oceanic Technology $15,522-534$.

- Marchesiello, P., McWilliams, J.C., Shchepetkin, A., 2003. Equilibrium structure and dynamics of the California current system. J. Phys. Oceanogr. 33 (4), 753783.

- Metso, A., Wells, G.S., Vaudrey, D.J., Cresswell, G.R., 1986. Satellite-tracked buoy data, July 1982 to September 1984. CSIRO Mar. Lab. Rep. No. 180, Hobart, 50 pp.

- $\quad$ Morrow, R., Birol, F., Griffin, D., Sudre, J., 2004. Divergent pathways of cyclonic and anticyclonic ocean eddies. Geophys. Res. Lett. 31, L24311, doi: 10.1029/2004GL020974, 5 pp.

- Nakata, H., Kimura, S., Okazaki, Y., Kasai, A., 2000. Implications of mesoscale eddies caused by frontal disturbances of the Kuroshio Current for anchovy recruitment. ICES J. Mar. Sci. 57, 143-152. 
- Nof, D., 1983. The translation of isolated cold eddies on a sloping bottom DeepSea Res., 30, 171-182.

- Paillet, J., Le Cann, B., Carton, X, Morel, Y., Serpette, A., 2002. Dynamics and Evolution of a Northern MEDDY J. Phys. Oceanogr. 32 (1), 55-79.

- Pascual, A., Faugère, Y., Larnicol, G., Le Traon, P.-Y., 2006. Improved description of the ocean mesoscale variability by combining four satellite altimeters. Geophys. Res. Lett. 33, L02611, doi:10.1029/2005GL024633, 4 pp.

- Peliz, A., Dubert, J., Haidvogel, D.B., Le Cann, B., 2003. Generation and unstable evolution of a density-driven Eastern Poleward Current: The Iberian Poleward Current. J. Geophys. Res. 108, 3268, doi: 10.1029/2002JC001443, $19 \mathrm{pp}$.

- Penven, P., Lutjeharms, J.R.E., Marchesiello, P., Roy, C., Weeks, S.J., 2001. Generation of cyclonic eddies by the Agulhas Current in the Lee of the Agulhas Bank. Geophys. Res. Lett. 27 (6), 1055-1058.

- Pingree, R.D., Le Cann, B., 1990. Structure, strength and seasonality of the slope currents in the Bay of Biscay region. J. Mar. Biol. Assoc. U.K. 70, 857885.

- Pingree, R.D., Le Cann, B., 1991. Drifting buoy in the field of flow of two eddies on east Thulean Rise (Northeast Atlantic). Journal of Geophysical Research 96(C9): doi: 10.1029/91JC01451.

- Pingree, R.D., Le Cann, B., 1992a. Three anticyclonic Slope Water Oceanic eDDIES (SWODDIES) in the southern Bay of Biscay in 1990. Deep-Sea Res. $39(7 / 8), 1147-1175$.

- Pingree, R.D., Le Cann, B., 1992b. Anticyclonic eddy X91 in the southern Bay of Biscay, May 1991 to February 1992. J. Geophys. Res. 97 (C9), 1435314367.

- Pingree, R.D., Le Cann, B., 1993. A shallow MEDDY (a SMEDDY) from the secondary Mediterranean salinity maximum. J. Geophys. Res. 98(C11), 2016920185.

- Pingree, R.D., 1994. Winter warming in the southern Bay of Biscay and lagrangian eddy kinematics from deep-drogued Argos buoy. J. Mar. Biol. Assoc. U.K. 74(1), 107-128.

- Pingree, R.D., 1995. The droguing of MEDDY pinball and seeding with Alace floats. J. Mar. Biol. Assoc. U.K. 75(1), 235-252. 
- Pingree, R.D., 1996. A Shallow Subtropical Subducting Westward Propagating Eddy (Swesty). Phil. Trans. R. Soc. A. 354, 979-1026.

- Pingree, R.D., Sinha, B., New, A.L., Waddington, I., Head, R.N., 1996. Will deep Subtropical Ring 'Storm Physalia' cross the Mid Atlantic Ridge and reach America? J. Mar. Biol. Assoc. U.K. 76, 553-567.

- Pingree, R.D., Sinha, B., 1998. Dynamic topography (ERS-1/2 and seatruth) of subtropical ring (Storm 0) in the Storm corridor (32-34 N, Eastern Basin, North Atlantic Ocean). J. Mar. Biol. Assoc. U.K. 78, 351-376.

- Pingree, R.D., Sinha, B., Griffiths, C.R., 1999. Seasonality of the European slope current (Goban Spur) and ocean margin exchange. Cont. Shelf Res., 19(7), 929-975.

- Pingree, R.D., Garcia-Soto, C., 2004. Annual westward propagating anomalies near $26^{\circ} \mathrm{N}$ and eddy generation south of the Canary Islands: remote sensing (altimeter/SeaWiFS) and in situ measurement. J. Mar. Biol. Assoc. U.K. 84(6), 1105-1115.

- Quadfasel, D., Frische, A., Cresswell, G., 1996. The circulation in the source area of the South Equatorial Current in the eastern Indian Ocean. J. Geophys. Res. 101 (C5), 12483-12488.

- Reverdin, G, Gascard, J.-C., Le Cann, B., Prieur, L., Assenbaum, M., Lherminier, P., 2009. A Long-Lasting Mode Water Vortex in the Northeast Atlantic Ocean. J. Phys. Oceanogr. 39 (3), 536-558.

- Rio, M.H., Guinehut, S., Larnicol, G., 2011. New CNES-CLS09 global mean dynamic topography computed from the combination of GRACE data, altimetry, and in situ measurements, J. Geophys. Res., 116, C07018, doi: 10.1029/2010JC006505.

- Rubio, A., Blanke, B., Speich, S., Grima, N., Roy, C., 2009. Mesoscale eddy activity in the southern Benguela upwelling system from satellite altimetry and model data. Prog. Oceanogr. 83 (1-4), Eastern Boundary Upwelling Ecosystems Symposium, 288-295.

- Sánchez, F., Gil, J., 2000. Hydrographic mesoscale structures and Poleward Current as a determinant of hake (Merluccius merluccius) recruitment in southern Bay of Biscay. ICES J. Mar. Sci. 57, 152-170.

- Sánchez, R., Gil, J., 2004. 3D structure, mesoscale interactions and potential vorticity conservation in a SWODDY in the Bay of Biscay. J. Mar. Syst. 46 (1-4), 47-68.

- Sangrà. P., Pascual, A., Rodríguez-Santana, A., Machín, F., Mason, E., 
McWilliams, J.C., Pelegrí, J.L., Dong, C., Rubio, A., Arístegui, J., Marrero-Díaz, A., Hernández-Guerra, A., Martínez-Marrero, A., Auladell, M., 2009. The Canary Eddy Corridor: A major pathway for long-lived eddies in the subtropical North Atlantic. Deep-Sea Res. I 56 (12), 2100-2114.

- Saunders, P.M., King, B.A., 1995. Bottom currents derived from a Shipborne ADCP on the WOCE Cruise All in the South Atlantic, J. Phys. Oceanogr., 25, 329-347.

- Shchepetkin, A.F., McWilliams, J.C., 2005. The regional oceanic modeling system (ROMS): A split-explicit, free-surface, topography-following-coordinate oceanic model. Ocean Model. 9, 347-404.

- Shoosmith, D.R., Richardson, P.L., Bower, A.S., Rossby, H.T., 2005. Discrete eddies in the northern North Atlantic as observed by looping RAFOS floats. Deep-Sea Res. II 52 (3-4), 627-650.

- Simpson, J.J., 1982. Offshore mesoscale eddies in the California Current System: Historical evidence. EOS Transactions, American Geophysical Union 63, 1004.

- Simpson, J.J., Dickey, T.D., Koblinsky, C.J., 1984. An Offshore Eddy in the California Current System. Part I: Interior Dynamics. Prog. Oceanogr. 13, 5-50.

- Souza, J.M.A.C., de Boyer Montégut, C., Le Traon, P.Y., 2011. Comparison between three implementations of automatic identification algorithms for the quantification and characterization of mesoscale eddies in the South Atlantic Ocean, Ocean Sci. 7, 317-334.

- Volkov, D.L., Fu, L.-L., 2008. The role of vorticity fluxes in the dynamics of the Zapiola Anticyclone. J. Geophys. Res., 113, C11015, doi: 10.1029/2008JC004841. 


\section{Figure captions}

Figure 1. (Left) Location of the area of study, within the Bay of Biscay. The solid line represents the limits of the grid in the model simulation. (Right) Study area and the main topographic structures; the location of the AGL buoy $(2850 \mathrm{~m})$ is indicated with a circle, whilst the location of the Matxitxako buoy $(550 \mathrm{~m})$ is indicated with a cross. Isobaths (m): 200, 1000, 2000, 3000 and 4000.

Figure 2. Monthly climatologies of SLA (the spatial mean has been removed from every map to ease the comparison between different months) and GCA for the study area for 2003 to 2010. Isobaths (m): 200, 1000, 2000, 3000 and 4000.

Figure 3. Lifetimes of anticyclonic eddies present for more than 5 weeks, within the areas shown in Figure 1 and tracked from: monthly altimetry SLA and GCA maps and from the wavelet method applied to altimetry and ROMS data.

Figure 4. (a) Trajectory, initial (asterisks) and final (diamonds) position, of eddies tracked in 3D with the wavelets analysis applied to the numerical simulations. Number of weeks an anticyclonic eddy is tracked in this area by means of the wavelet analysis from altimetry (b) and simulations (c) and over 2003-2010 (grey squares correspond to an area of $0.1^{\circ}$ of latitude and longitude). The solid line represents the limits of the area given for the eddy tracking. Isobaths (m): 200, 1000, 2000, 3000 and 4000.

Figure 5. Monthly climatologies of EKE spatially averaged for the area $4^{\circ} \mathrm{W}$ to $3^{\circ} \mathrm{W}$ and $44^{\circ} 12^{\prime} \mathrm{N}$ to $44^{\circ} 30^{\prime} \mathrm{N}$ and estimated from altimetry maps (light grey line and left axis) and from ROMS outputs (dark grey line and right axis).

Figure 6. AVHRR derived SST $\left({ }^{\circ} \mathrm{C}\right)$ images. Altimetry derived weekly GCA vectors are superimposed (the date and the time delay, in days, between the SST image and the GCA vectors is indicated in each title), as well as the current vectors (integrated from 0 to $90 \mathrm{~m}$ depth) measured by the AGL and Matxitxako buoys (pink and dark blue, respectively), corresponding to the hour of the SST image. In the images corresponding to 19 January (a) and 26 January 2008 (b) the trajectory of the drifter corresponding to 10 days before and 10 days after the date of the images is also superimposed (black thick arrow); the initial position is indicated with a circle and the final position with a triangle. The white square in (a) frames the warm surface tongue. Isobaths (m): 200, 1000, 2000, 3000 and 4000.

Figure 7. Evolution of the currents measured by the AGL (top) and Matxitxako (bottom) buoys integrated from 0 to $90 \mathrm{~m}$ depth, from the beginning of January 2008 to the end of March 2008.

Figure 8. Altimetry derived mean SLA for March 2008 (a), AVHRR derived SST $\left({ }^{\circ} \mathrm{C}\right)(\mathrm{b}$ and $\mathrm{f}$ ) and MERIS derived Chl-a ( $\left.\mathrm{mg} \mathrm{m}^{-3}\right)(\mathrm{c}, \mathrm{d}, \mathrm{e}, \mathrm{g}$ and $\mathrm{h}$ ) images. Altimetry derived weekly GCA vectors are superimposed (the date and the time delay, in days, between the SST or Chl-a image and the GCA vectors is indicated in each title), as well as the 
current vectors (integrated from 0 to $90 \mathrm{~m}$ depth) measured by the AGL and Matxitxako buoys (pink and dark blue, respectively), corresponding to the hour of the SST image. From 15 April (c) to 20 May 2008 (h) the trajectory of the drifter corresponding to 10 days before and 10 days after the date of the images is also superimposed (black thick arrow); the initial position is indicated with a circle and the final position with a triangle. Isobaths (m): 200, 1000, 2000, 3000 and 4000.

Figure 9. (a) Altimetry derived mean SLA-GCA map corresponding to June and the trajectory of the drifter followed during June (black thick arrow); in the period form 10 days before to 10 days after the date of the images. (b) AVHRR derived SST $\left({ }^{\circ} \mathrm{C}\right.$ ) image corresponding to 8 July with altimetry derived weekly GCA vectors superimposed (the date and the time delay, in days, between the SST image and the GCA vectors is indicated in each title), as well as the currents vectors (integrated from 0 to $90 \mathrm{~m}$ depth) measured by the AGL buoy (pink arrow within a white rectangle) and Matxitxako buoy (dark blue arrow within a white rectangle), corresponding to the hour of the SST image. The trajectory of the drifter corresponding to 10 days before and 10 days after the date of the image is also superimposed (black thick arrow); the initial position is indicated with a circle and the final position with a triangle. (c) Mean SLAGCA map corresponding to the period between 16 July and 13 August and the trajectory of the drifter followed during 16 July to 10 August (black thick arrow). Isobaths (m): 200, 1000, 2000, 3000 and 4000.

Figure 10. (a, c, e) Snapshots of the eddy tracking applied to the relative vorticity at 50 $\mathrm{m}$ depth in the model simulations for eddies FEB08, MAY08 and MAR04, respectively. The trajectory of each eddy is given by the black bold line. (b, d, f) Snapshots of velocities and surface temperatures $\left({ }^{\circ} \mathrm{C}\right)$ associated with the simulated eddies FEB08, MAY08 and MAR04, respectively. Dates: (a) 17/03/2008, (b) $23 / 02 / 2008$, (c) $12 / 07 / 2008$ and (d) 8/07/2008 Note: The red line shows the section from which the vertical section of the eddy shown in Fig.12 has been extracted, (e) 27/06/2004, (f) 18/03/2004. Isobaths (m): 200, 1000, 2000, 3000 and 4000. Note: White cores in (c) and (e) show a maximum negative relative vorticity.

Figure 11. Main characteristics of three simulated eddies investigated using the 3D version of the eddy tracking wavelets-based utility. From top to bottom: deepest detection level (thin black line) and bathymetry (grey area); diameter and error in determination of the diameter; and drifting velocity and error in the drifting velocity.

Figure 12. Vertical section of the potential temperature (a) and the meridional component of the current (b) across the simulated eddy shown in Fig. 10d. Note: The isotherms of figure $12 \mathrm{a}$ are plotted every $0.5^{\circ} \mathrm{C}$, until $14^{\circ} \mathrm{C}$, where are shown every $1^{\circ} \mathrm{C}$. 

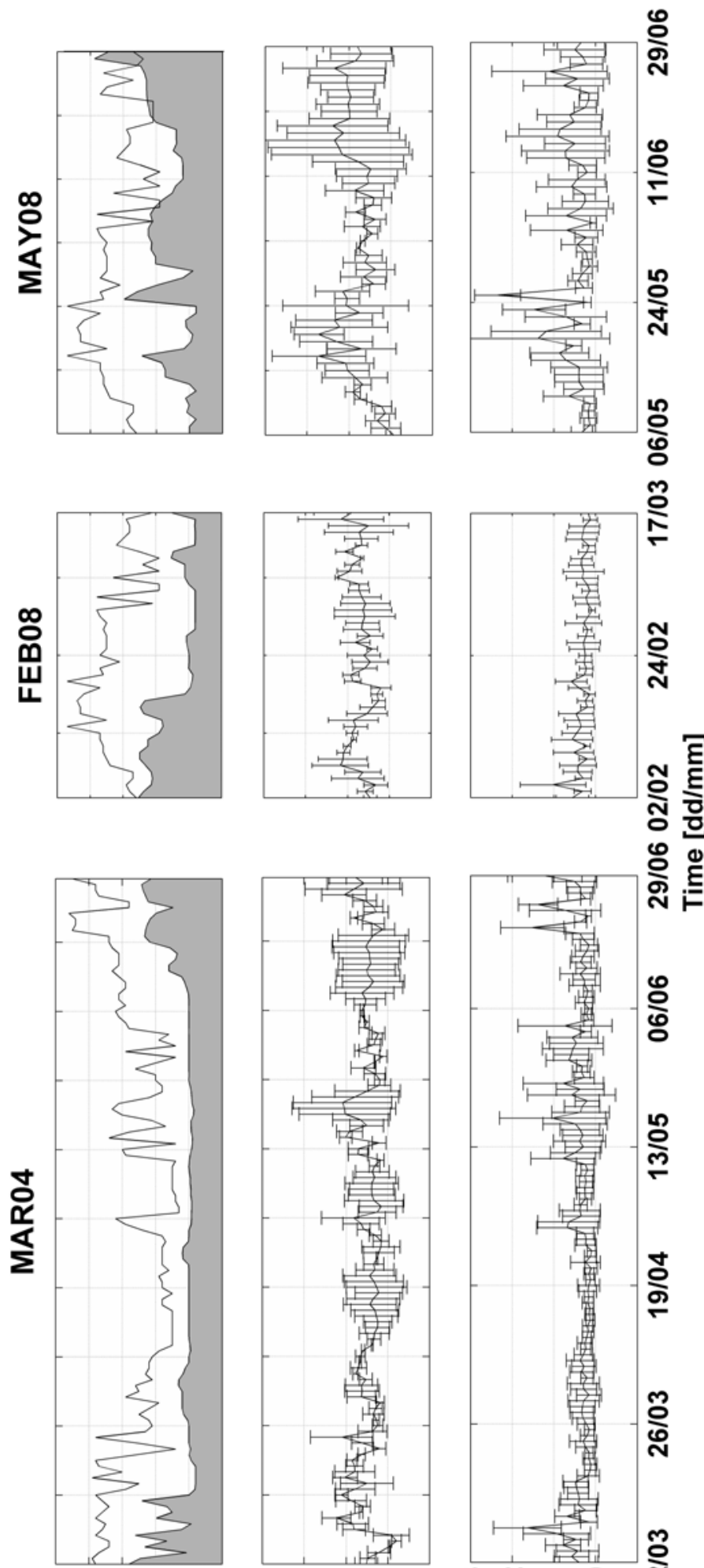

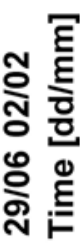

ฐั่

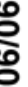

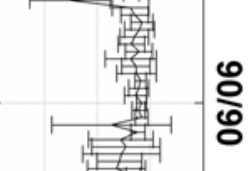

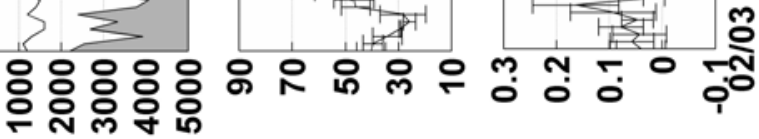

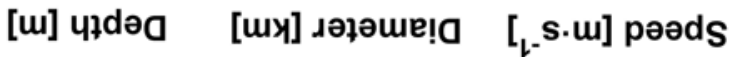


a)

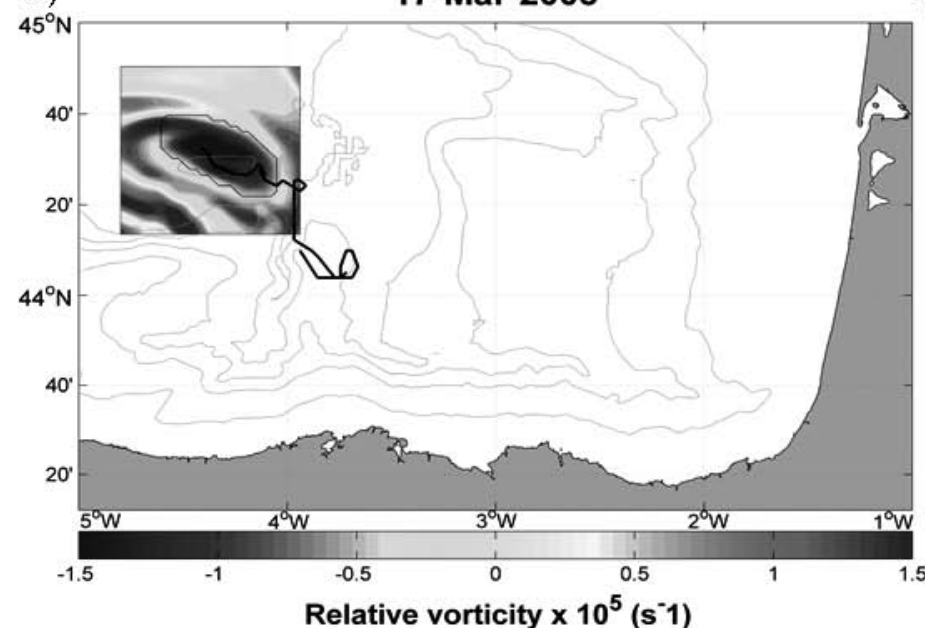

c)

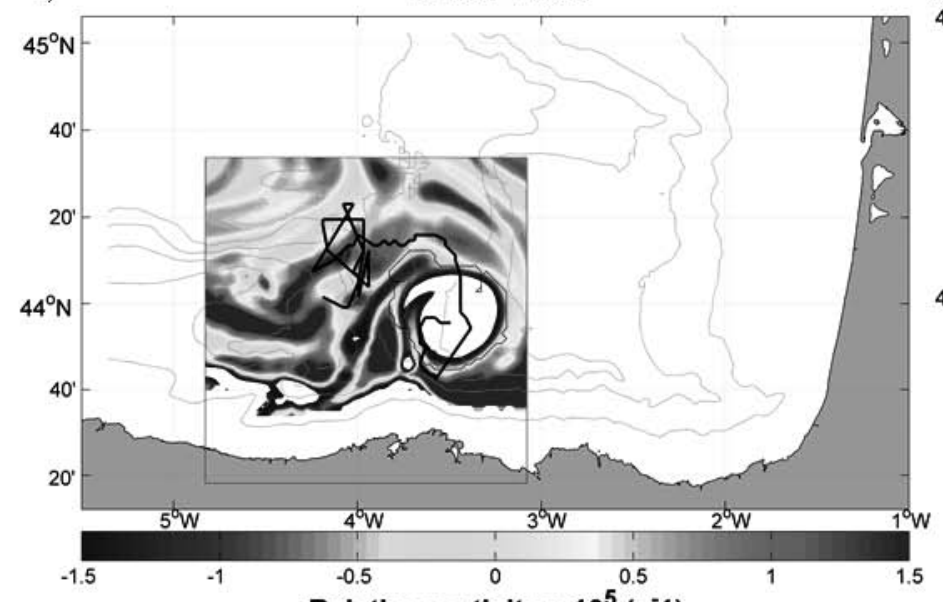

e)

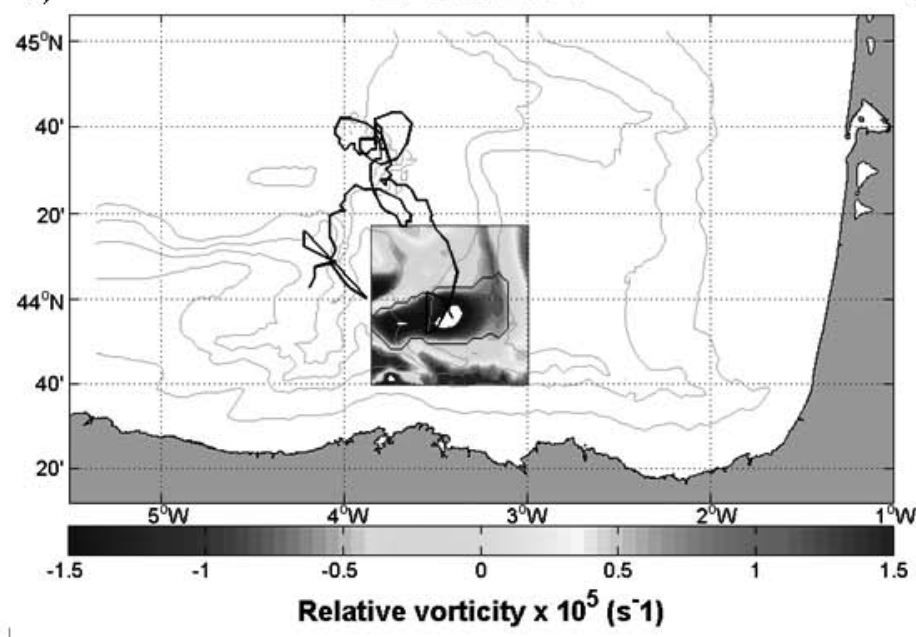

b)

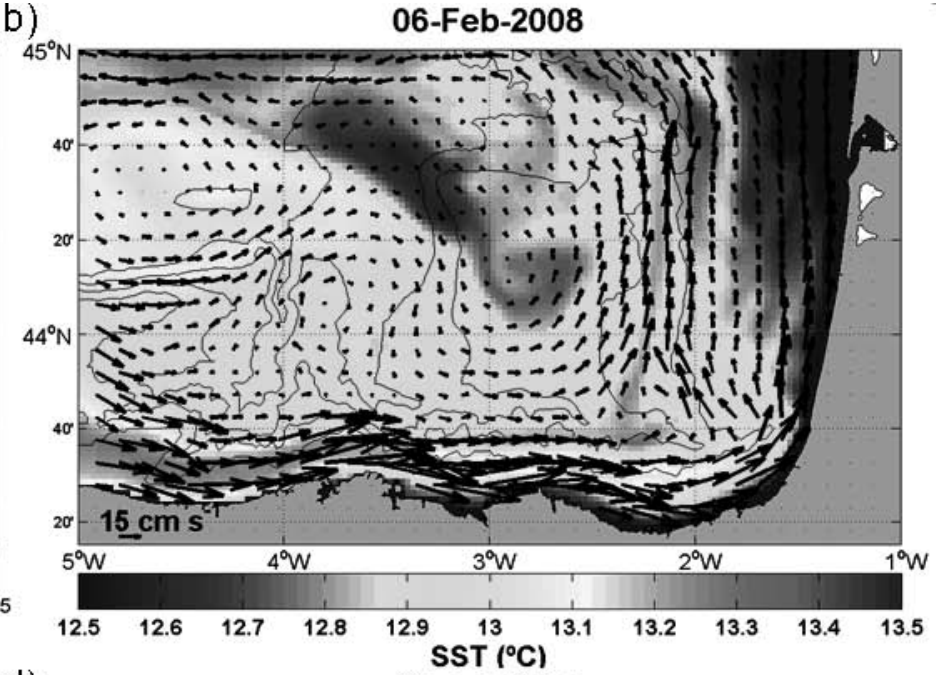

d)

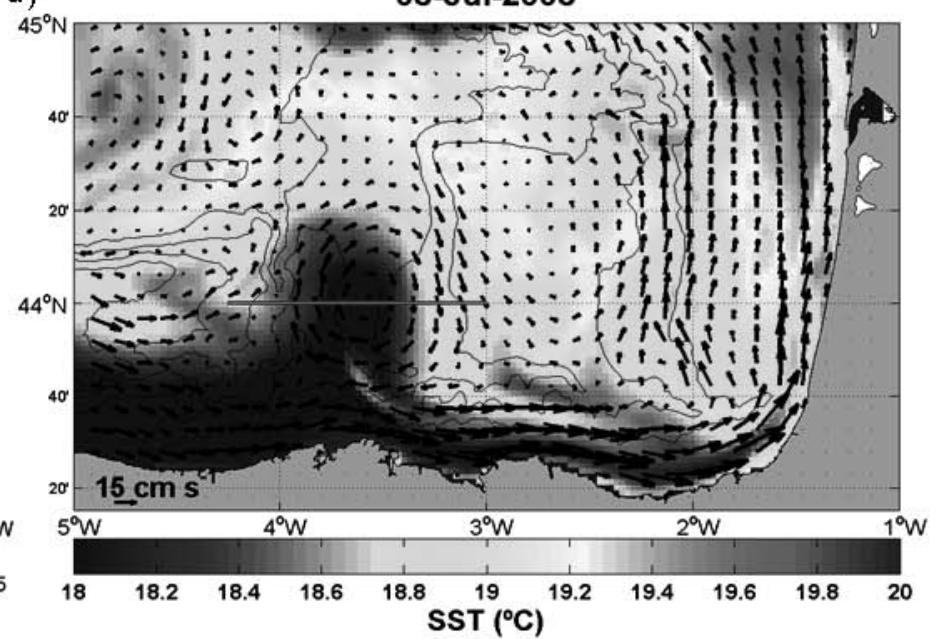

f)

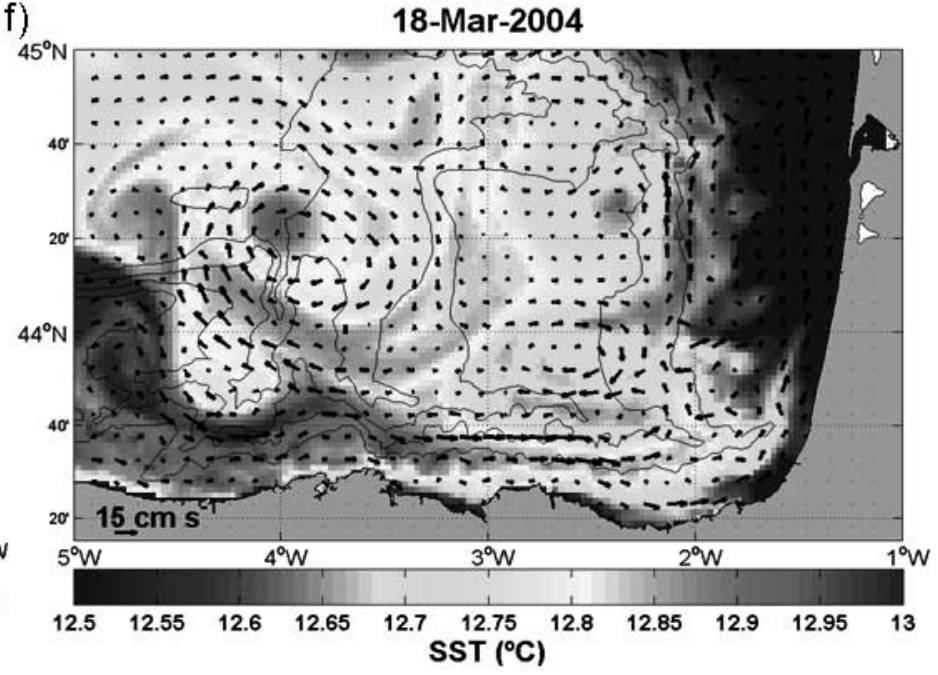




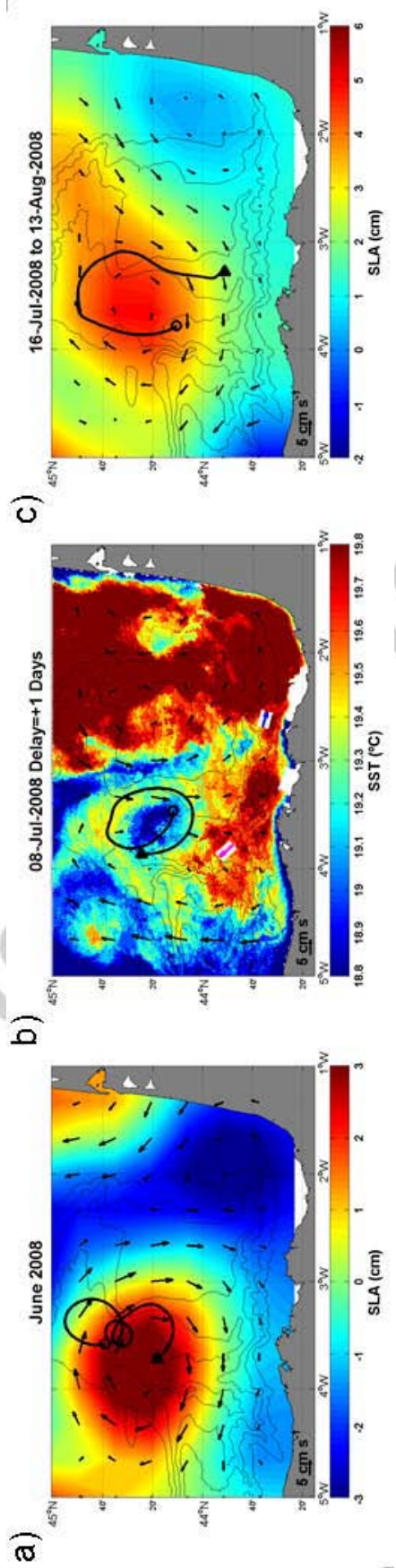


a)

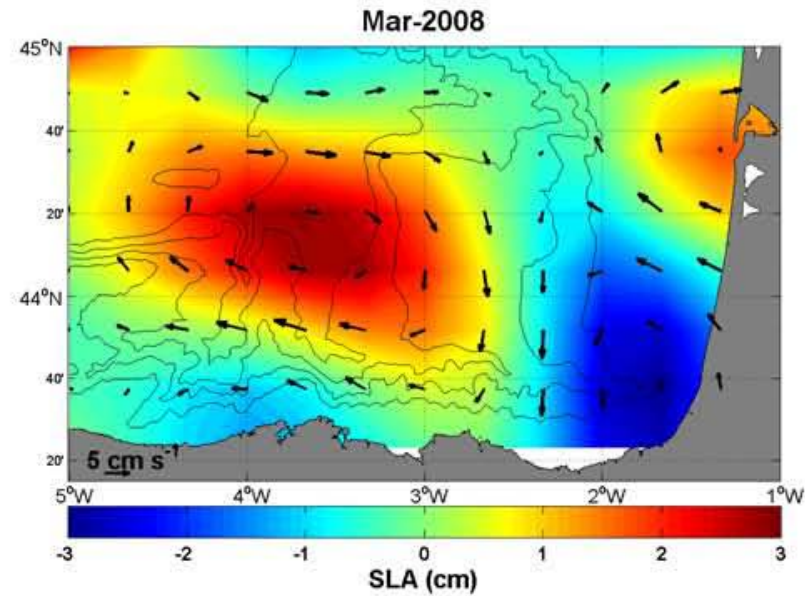

c)

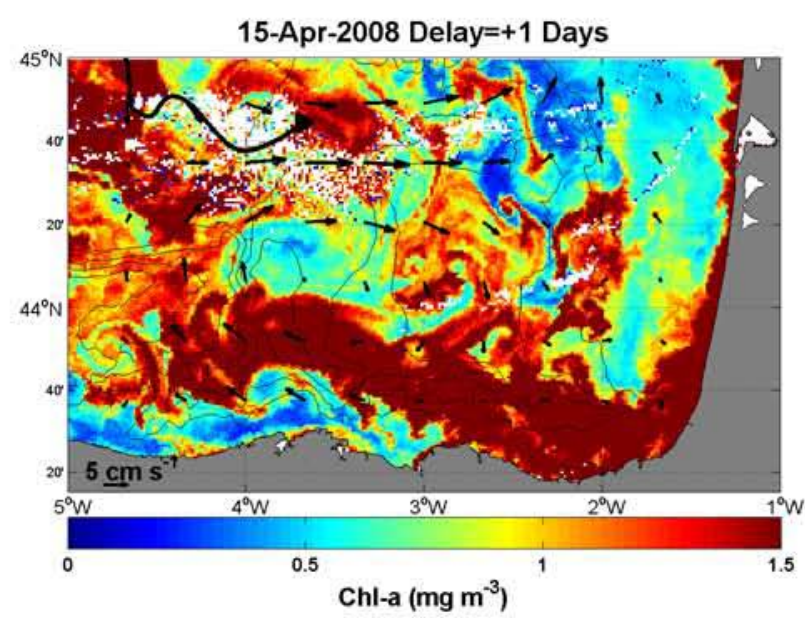

e)

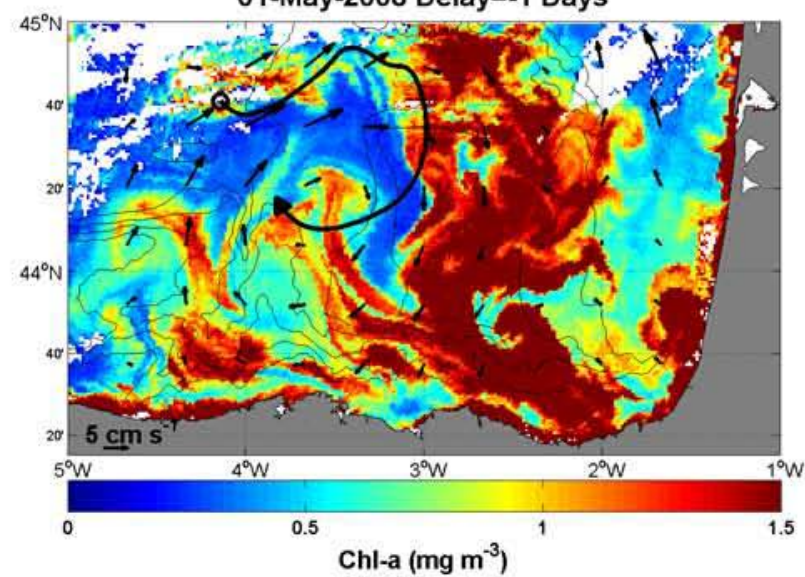

g)

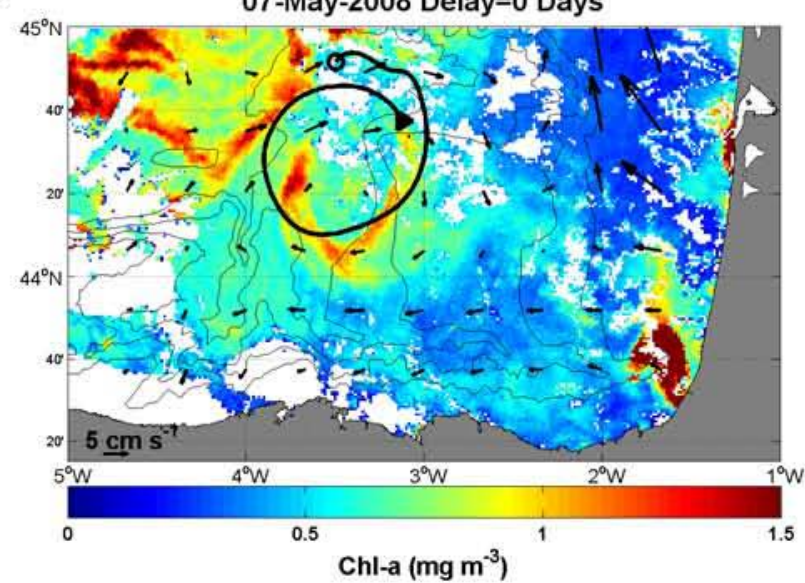

b)

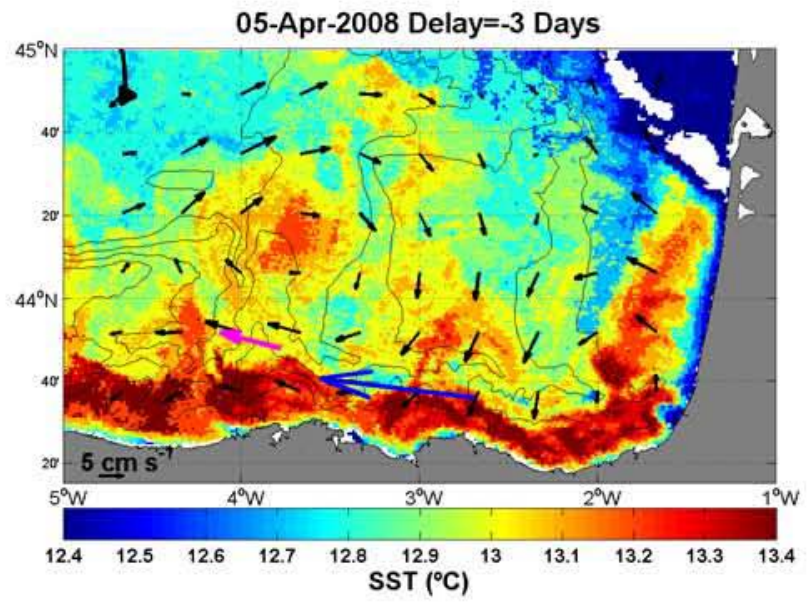

d)

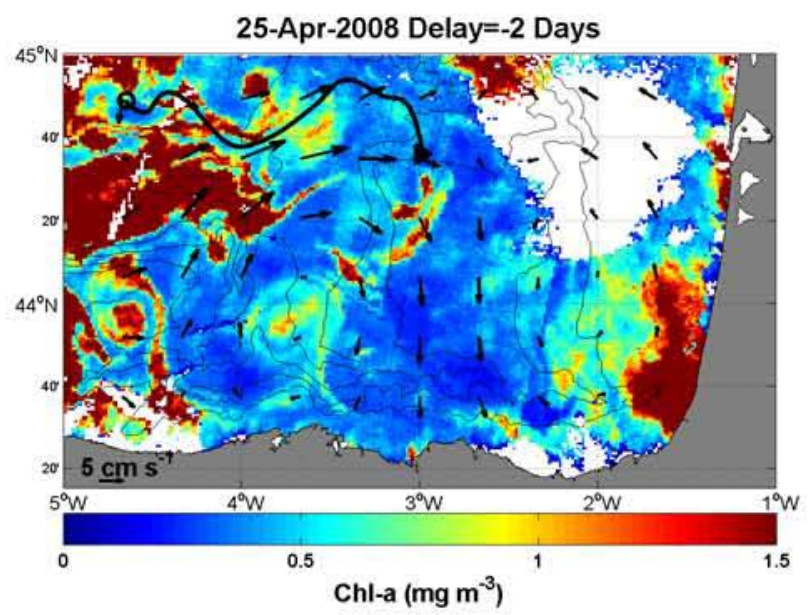

f)

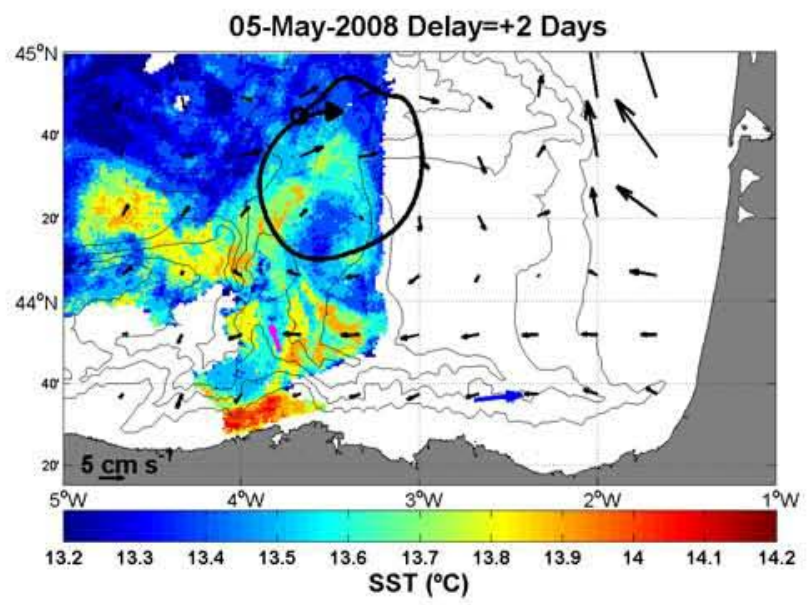

h)

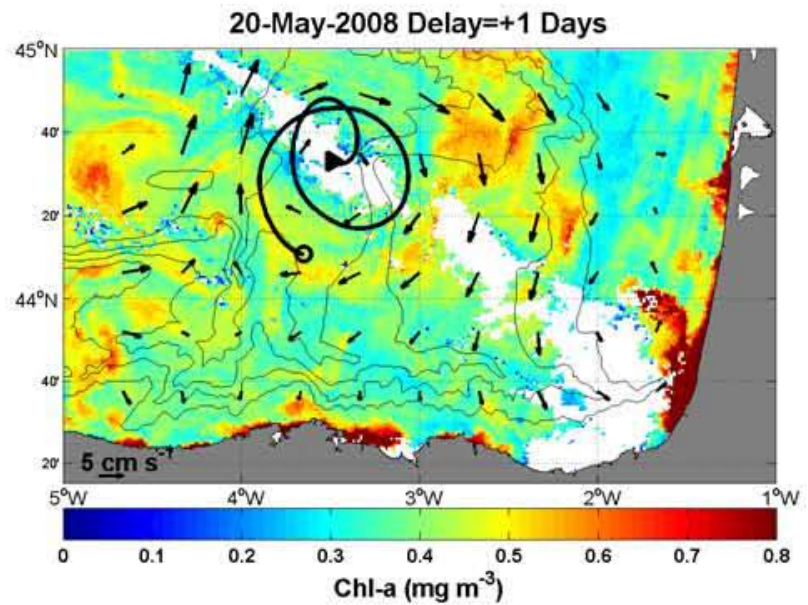




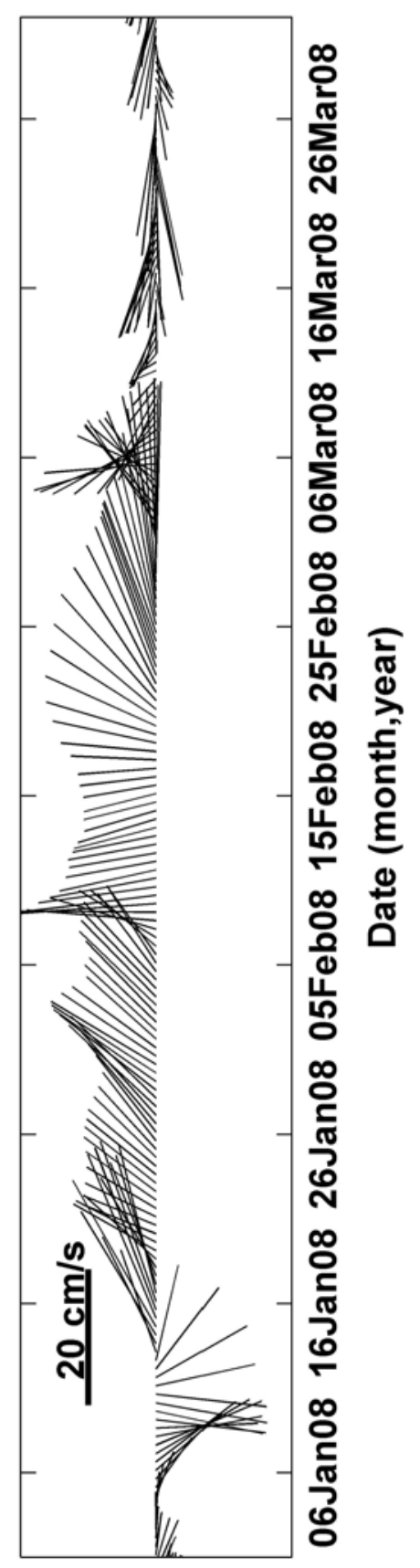




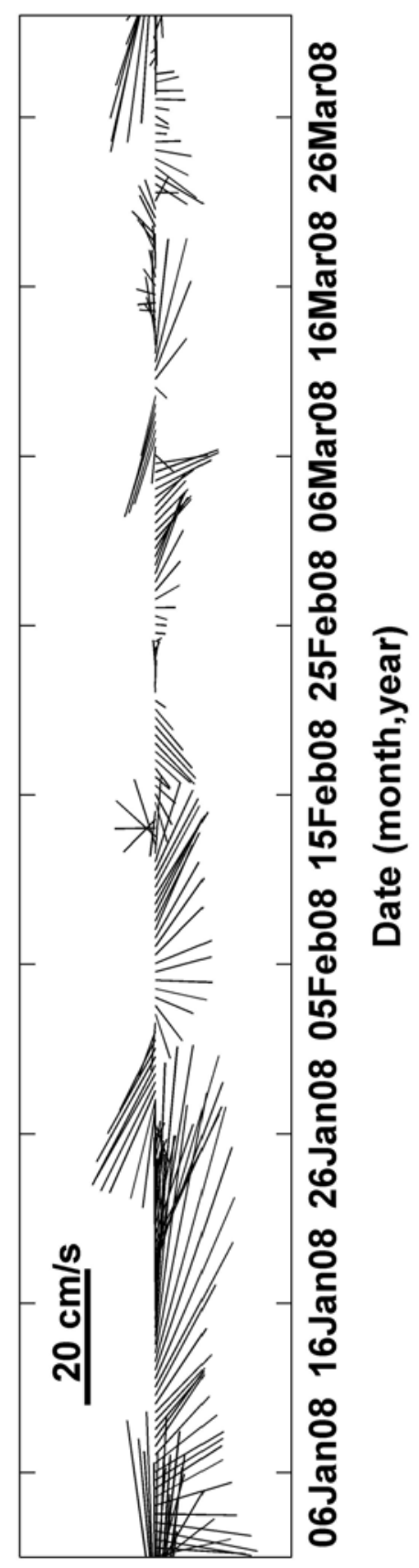




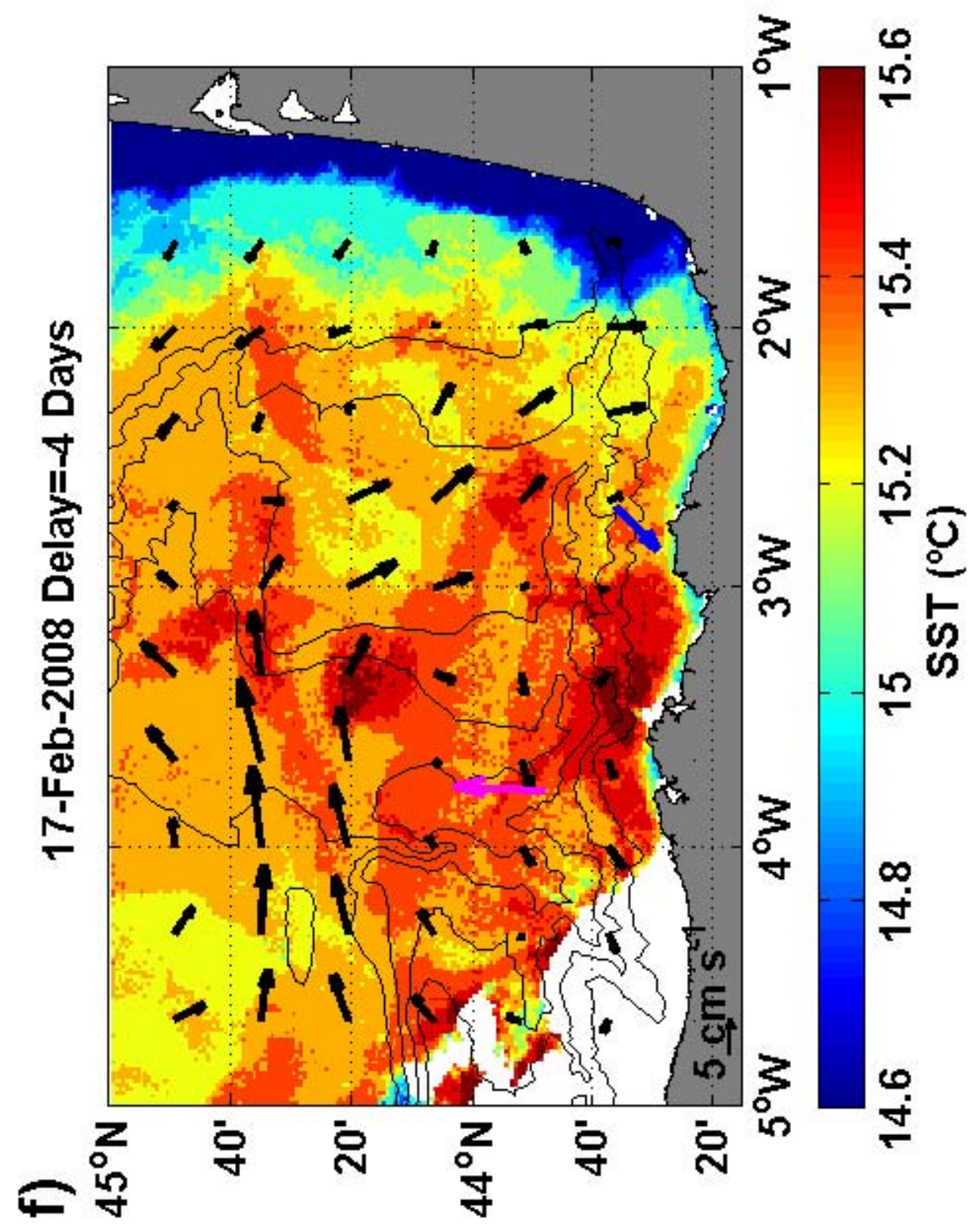




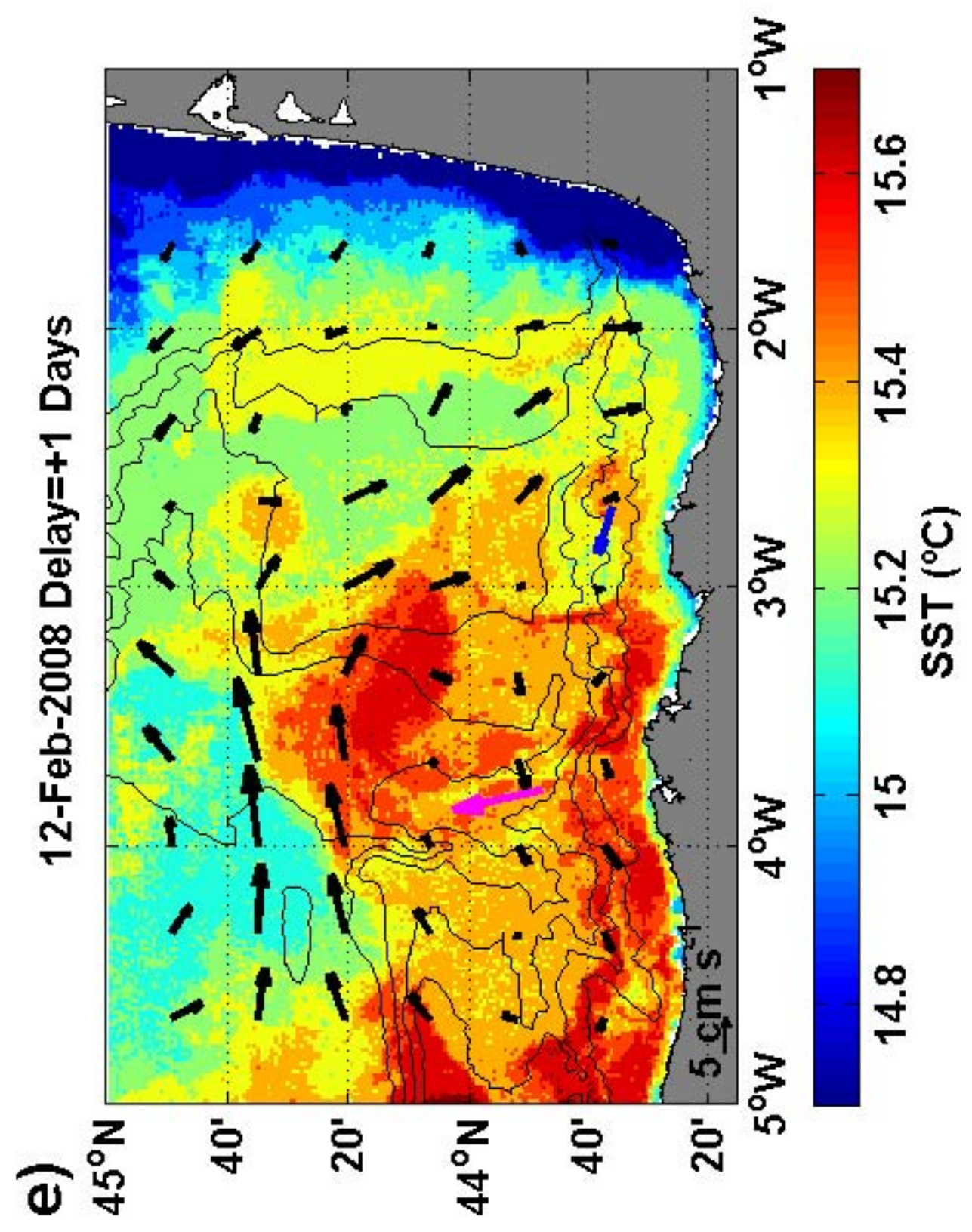




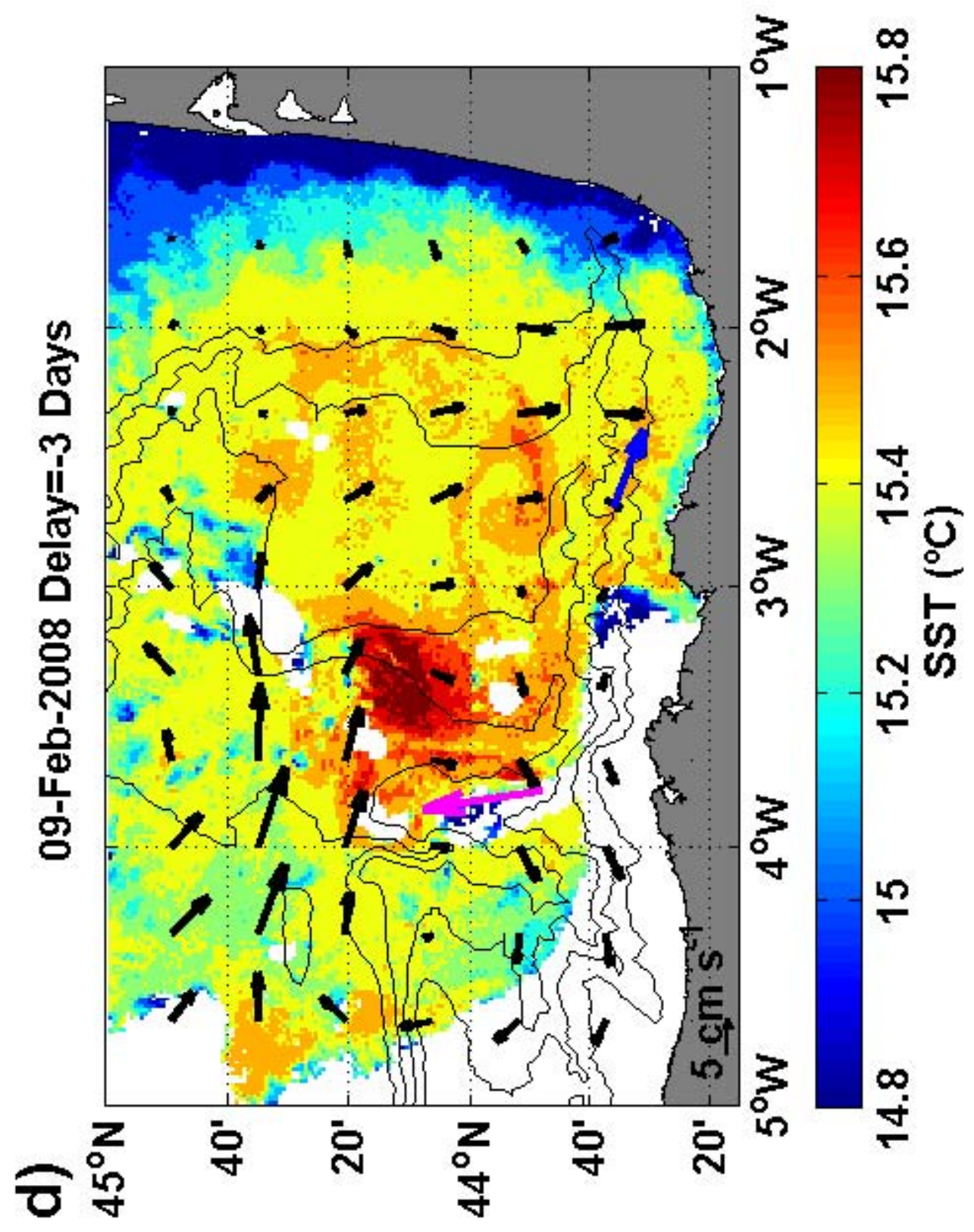




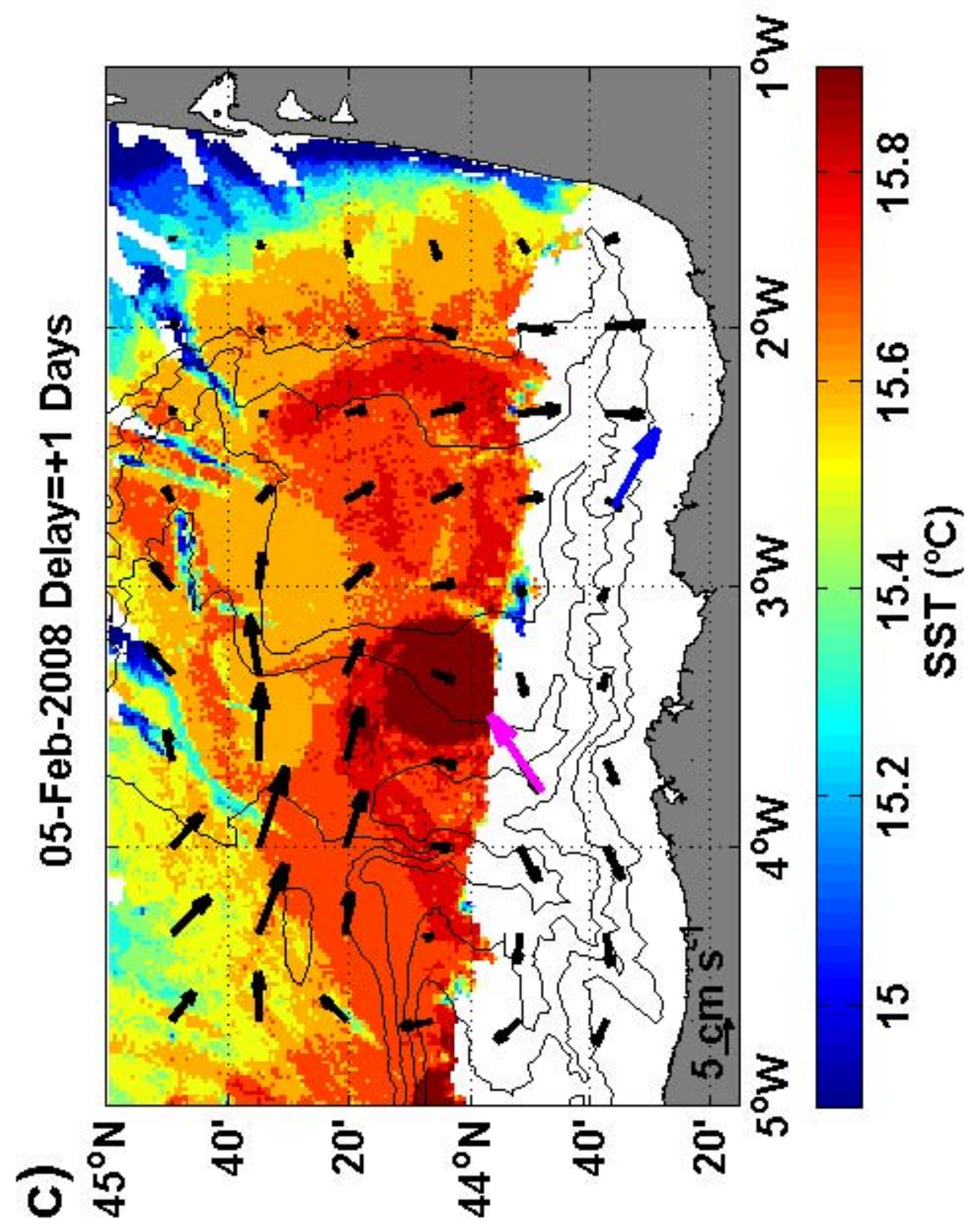




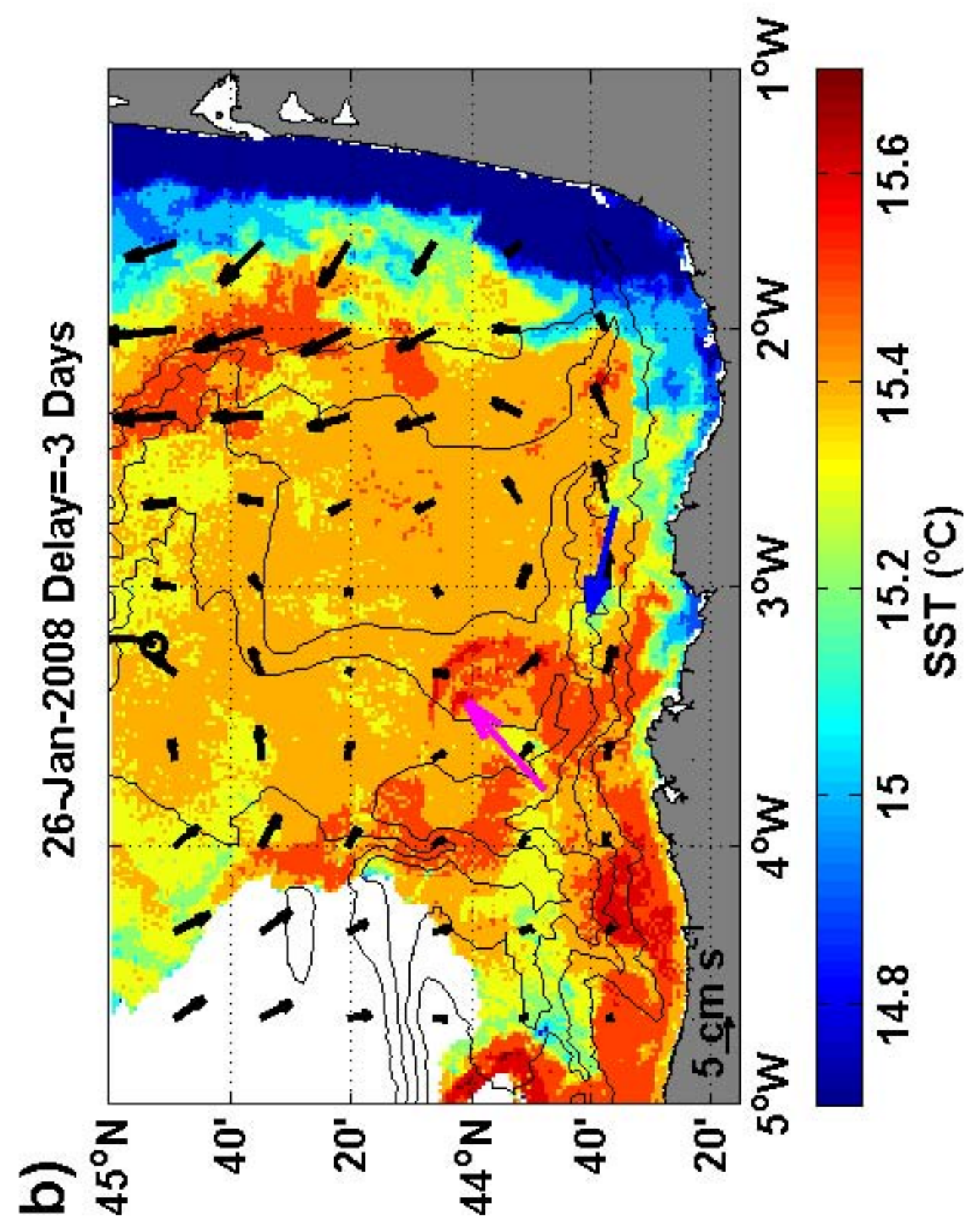




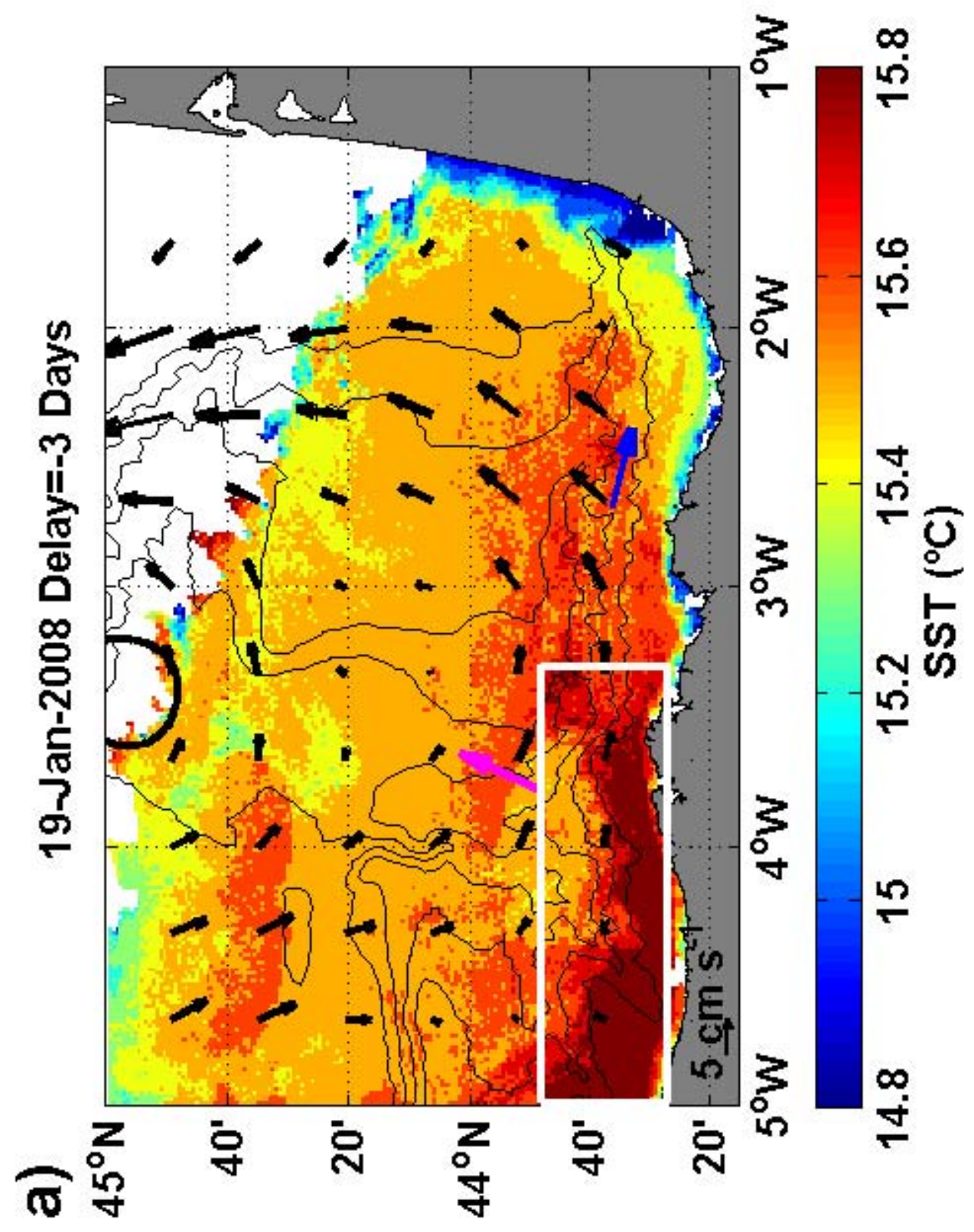




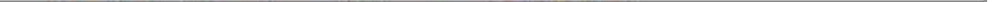



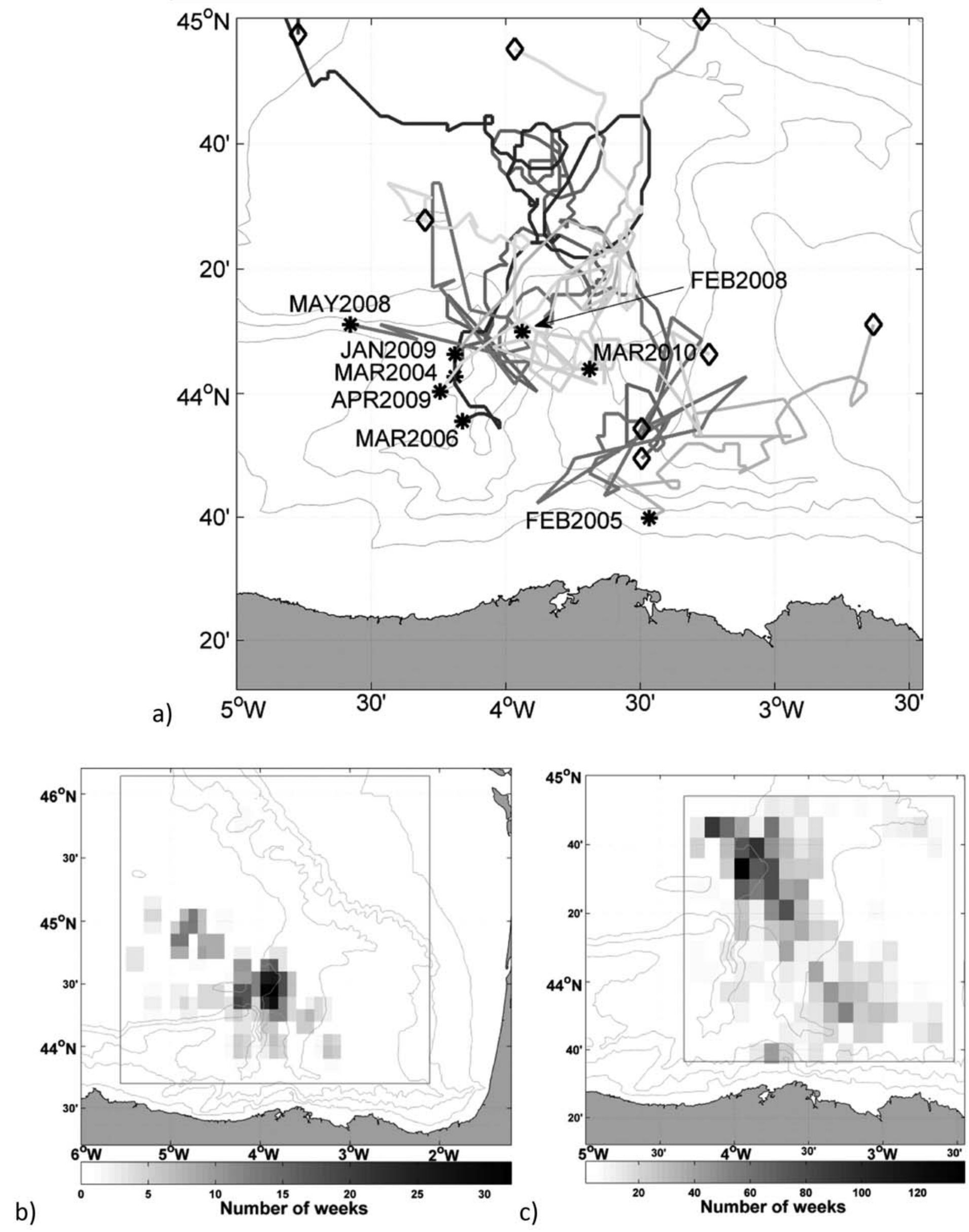


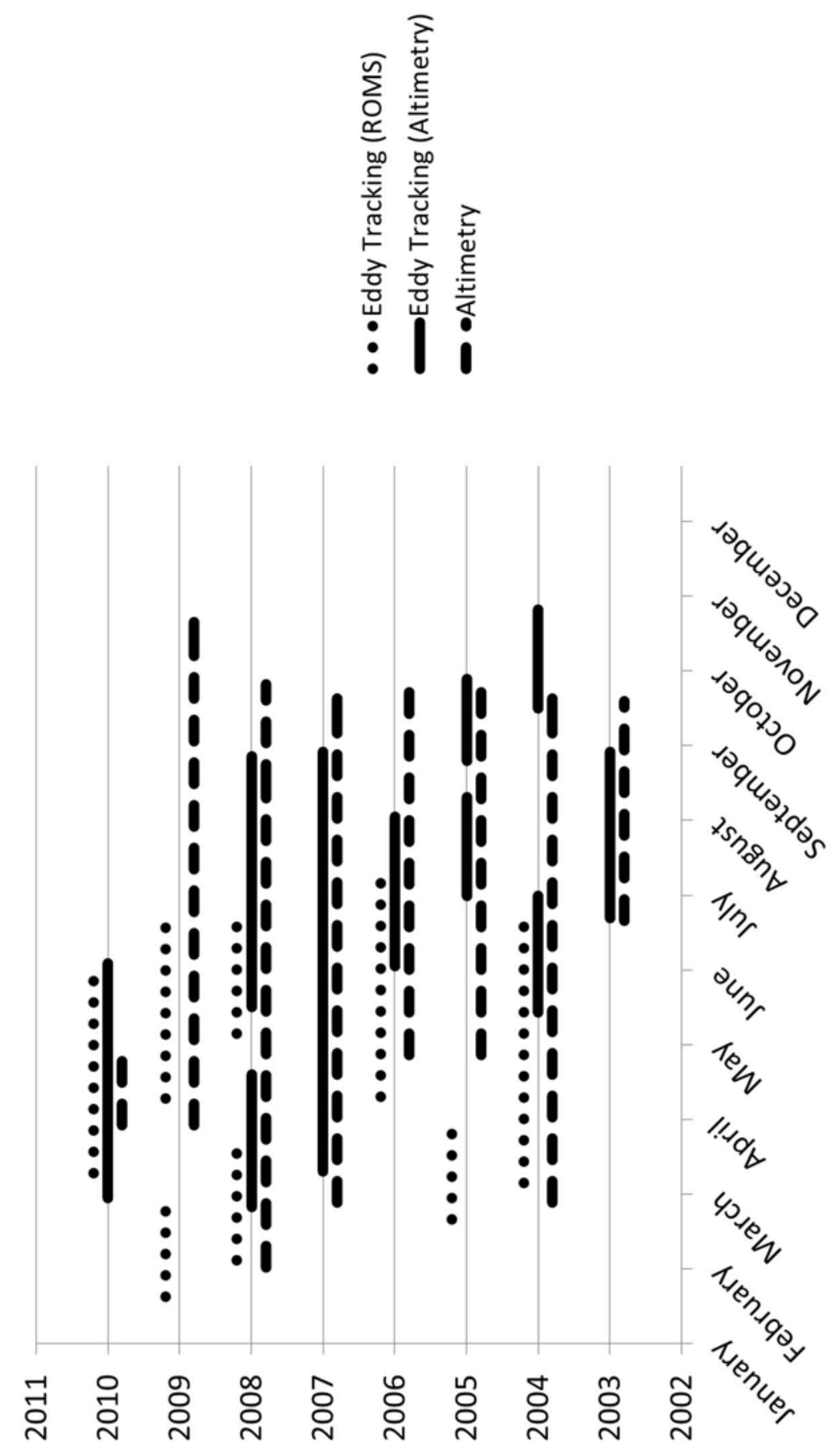



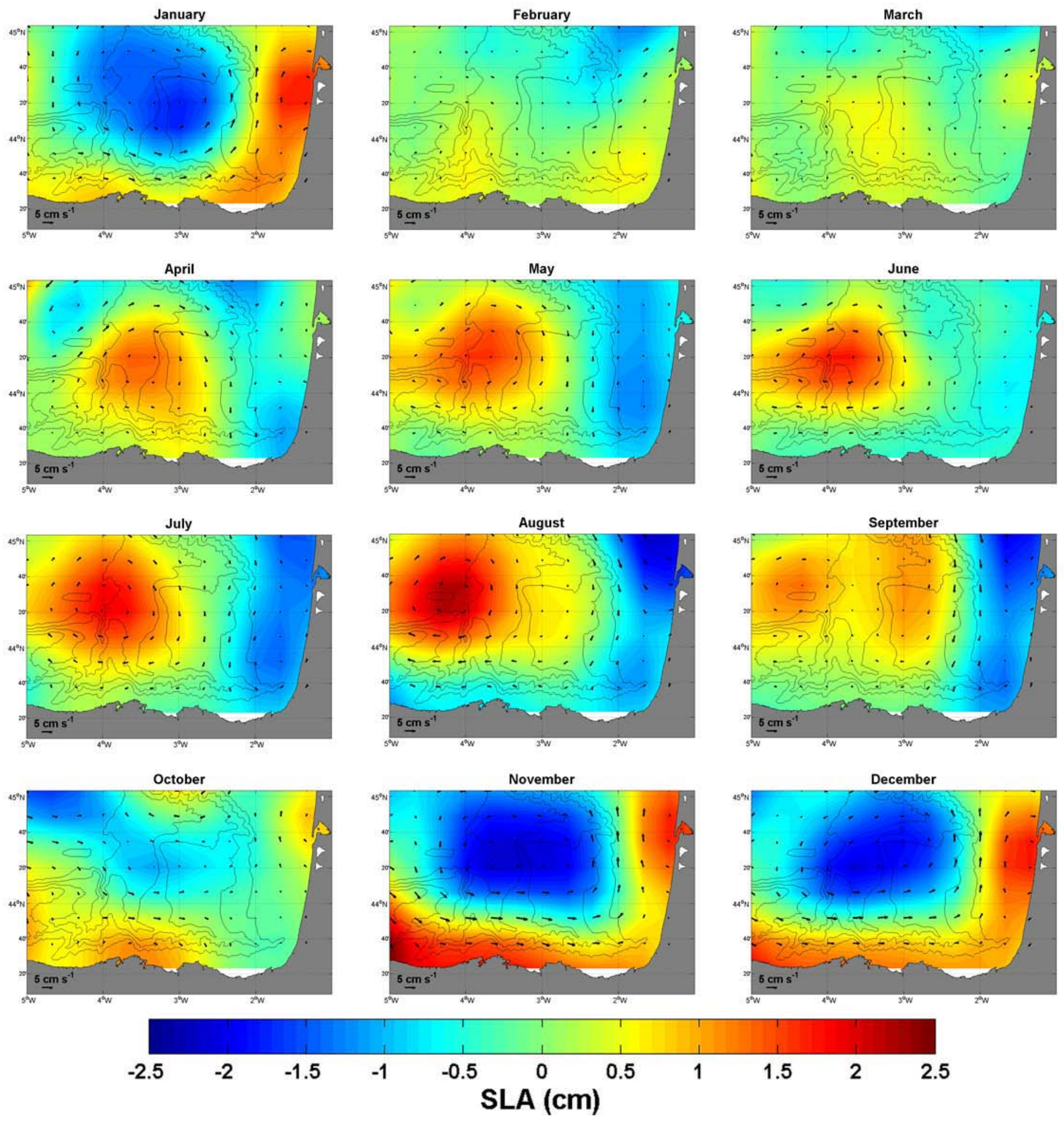

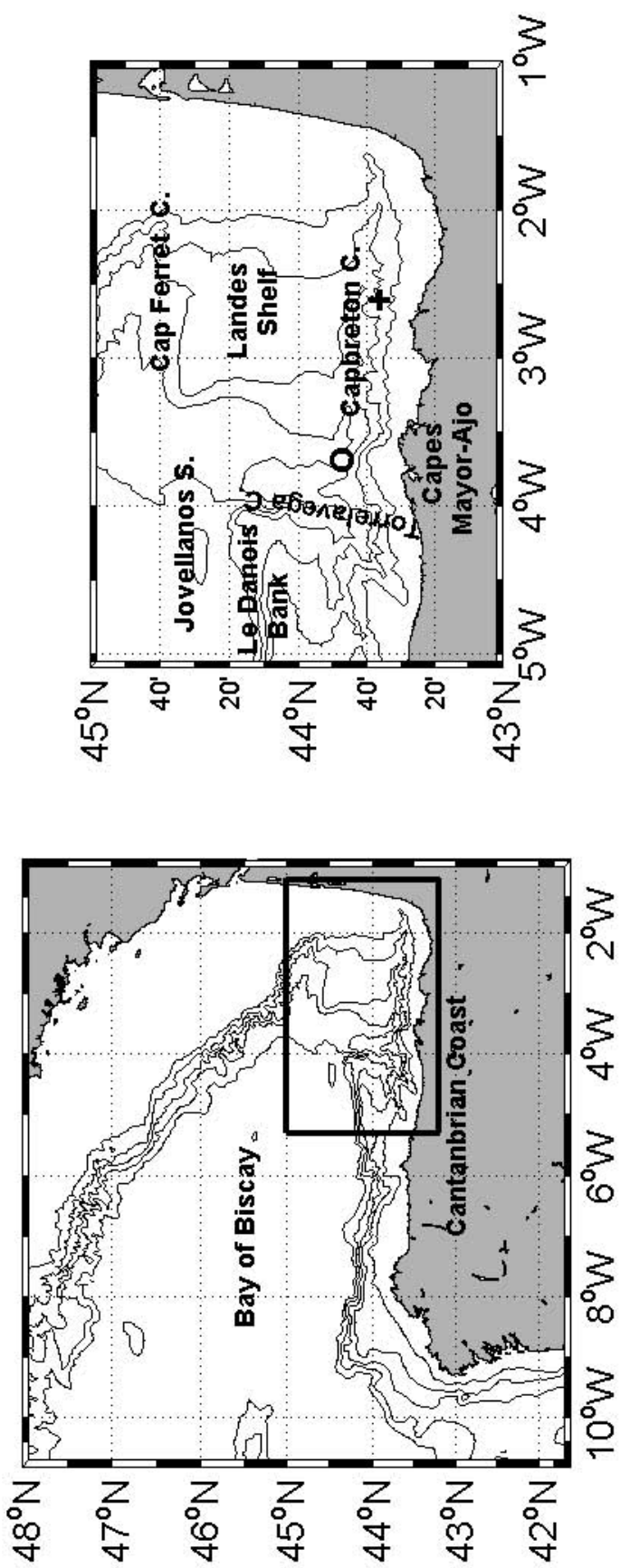
